اتجاهات طالبات كليه التربيه الرياضيه نحو التعليم المدمج وعلاقتها بمستوي الطموح لايهم والكفايات التربويه لاعضاء هيئه التدريس في ظل مستحدثات جائحه كورونا

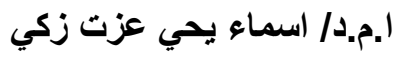

كليه التربيه الرياضيه بنات جامعه الزقازيق

مقدمة البحث

يعد علم اصول التربيه من العلوم التي ازداد إيمان العالم به باعتباره أساسا جوهريا لتفهم

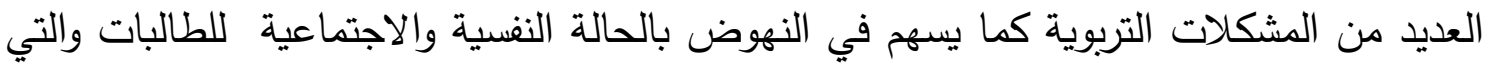
تسهم بقدر كبير في تحقيق الأهداف التي تسعي إليها العملية التعليميه، وتعتبر الاتجاهات والكفايات من أهم مواضيع علم اصول التربيه الاجتماعيه، وتمثل احدي المحددات الرئيسية للسلوك الاجتماعي.

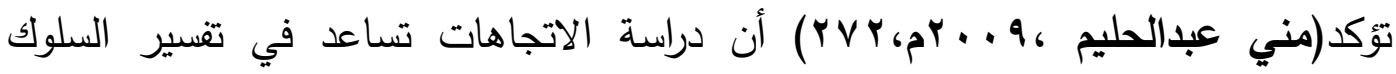

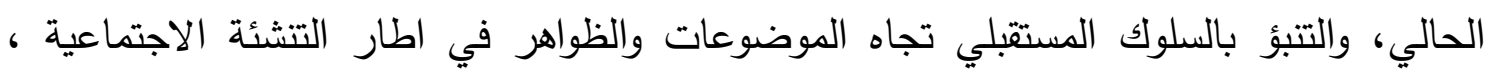
فالسلوك ليس وليد الصدفة بل هو انعكاس للإتجاهات التي تكتسب من وسائط التطبيع والاتصال الاجتماعي (كالأسرة ، والمدرسة ، والمجتمع).

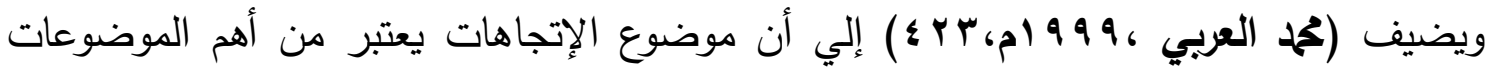

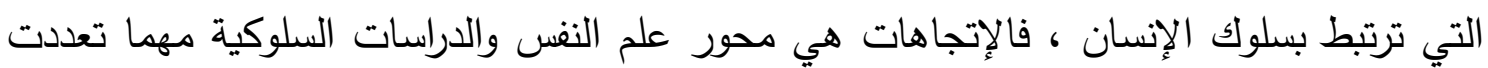

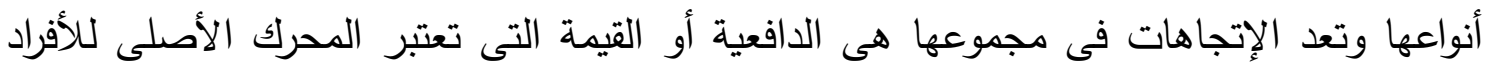
تجاة الأهداف وأنها الأساس الحركى الدينامى للجماعات.

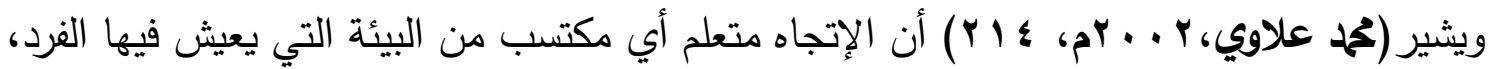
فالإتجاه هو ميل للإستجابة بشكل معين تجاه مجموعة خاصة أو معينة من المثيرات، كما أنه

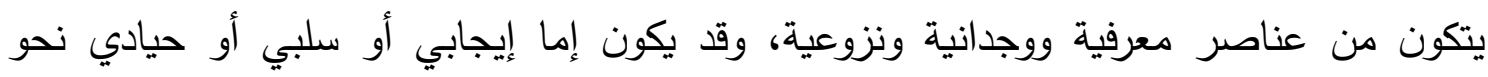
موضوع ما كالممارسة الرياضية مثلاً .

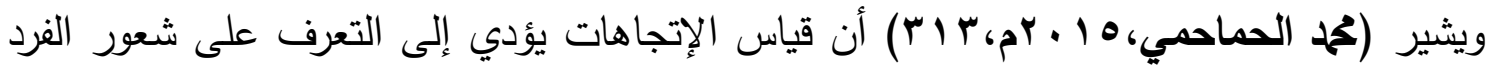

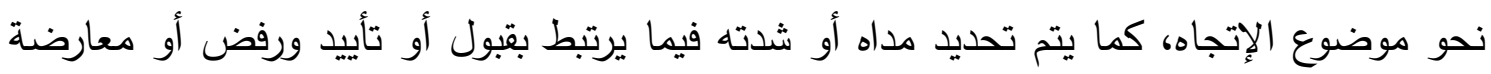


الموضوع المتصل به، ومن ثم يسمح قياس الإتجاهات بتوقع طبيعة سلوك الفرد نحو الموضوع الذي يتم قياسه أو تحديد مدى استجابته له .

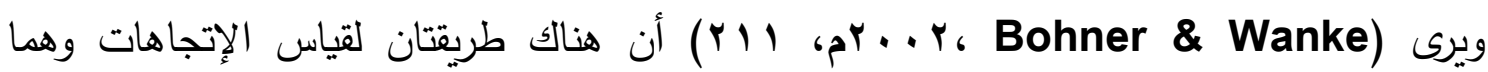
الطريقة المباشرة وهي مجموعة من الأسئلة التي يتم توجيهها للطالبه المراد قياس إتجاهها، والطريقة غير المباشرة والتي يتم فيها إستتاج الإتجاهات من أدلة أخرى غير الأسئلة المباشرة ، فالمقاييس غير المباشرة للإتجاهات تكثف الإتجاهات التي لا تكون الطالبه على وعي بها، وهي ما تسمى

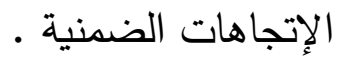

ومما لاشك فيه ان جائحة كورونا ضربت العالم على جميع المستويات "صحيًا واقتصاديًا وتعليميًا"، وادت إلى تغيير معتقدات كان يسير عليها قبل ظهور الفيروس، شملتها النظرة للتعليم في زمن "كوفيد 9 (". حيث فرضت الجائحة واقعا جديدا للتعليم بالاعتماد على نظام "التعليم المدمج" الذي كان بمثابة طوق النجاة للطلاب للحفاظ على عامهم الدراسي.

وقد اشار وزير التعليم العالي ( خالا عبد الغفار • ب. r) ان التعليم المدمج هو عملية الدمج بين المحاضرات المباشرة داخل الجامعة ووقوف المحاضر أمام طلابه والتفاعل وجها لوجه معهم، وبين التعليم عن بعد وذلك عن طريق كورسات معدة يتولى الطالب تسجيل بياناته بها، ليتمكن من دراسة

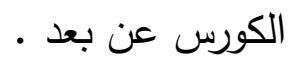

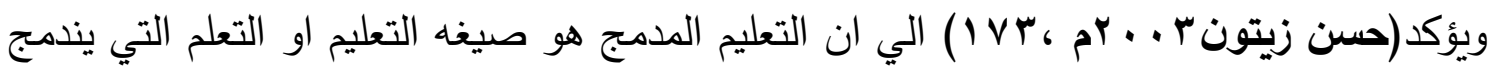
فيها التعليم الاككتروني مع التعليم التقليدي في اطار واحد حيث توظف ادوات التعليم الالكتروني سواء المعتمده علي الكمبيوتر او علي الشبكات في الدروس مثل معامل الكمبيوتر والصفوف الذكيه ويلتقي عضو هيئه التدريس مع الطالب وجهها لوجه معظم الاحيان.

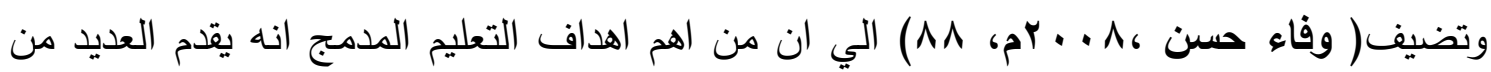
فرص التعلم بطرائق مختلفه والاستفاده من التكنولوجيا الحديثه ومواكبه العصر دون فقدان التواصل الاجتماعي والانساني التربوي الذي يتم داخل الفصول الاعتياديه.

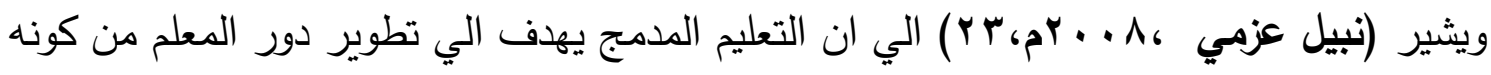
مصدرا وحيدا للمعرفه الي جعله مساعدا باعتماد مصادر تعليميه متعدده والتركيز علي عنصر التشويق والتجديد والتغيير في العمليه التعليميه . 


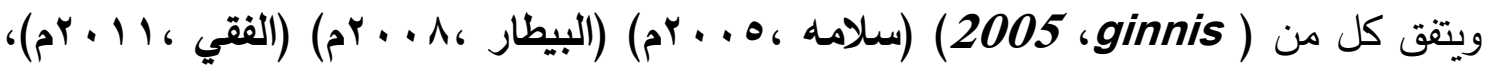

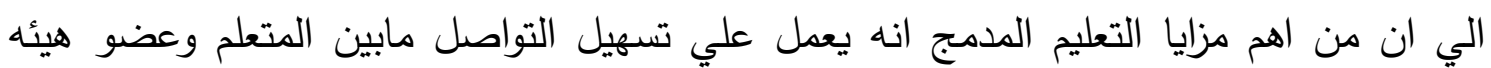
التدريس من جهه ومابين الطالبات انفسهم من جهه اخري من خلال توفير بيئه تفاعليه مستمره تمد الطالبات بالماده العلميه بصوره واضحه من خلال التطبيقات المختلفه .

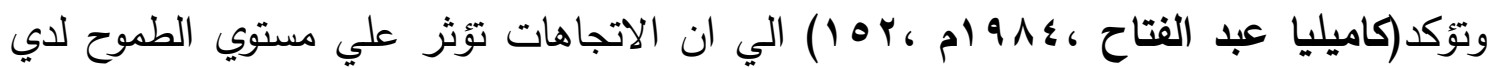
المراهقين بشكل مباشر فاذا كانت اتجاهات الجماعه سلبيه فانها ستؤثر بالسلب علي اتجاهات الطالبه اما اذا كانت ايجابيه فانها ستؤثر بالايجاب عليها لذا فان الطالبه تحدد مستوي طموحها باقرانها وجماعتها المرجعيه اكثر من تاثرها بوالديها ـاليه

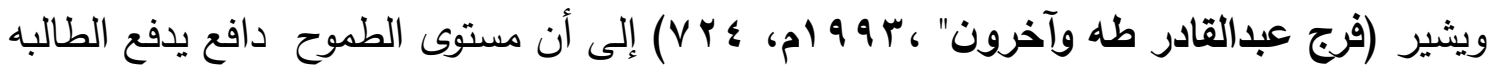

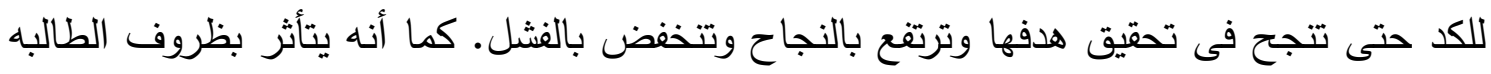
وخبراتها الإيجابية والسلبية.

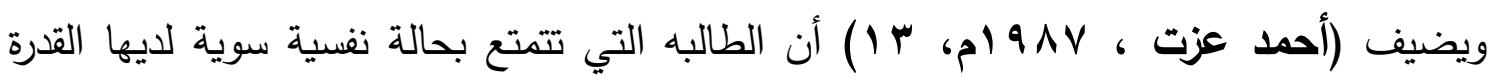
على فهم قدراتها ومن ثم تضع لنفسها مستوى من الطموح يتناسب مع هذه القدرات

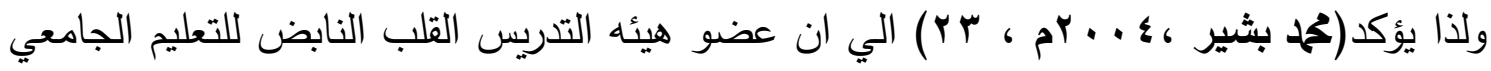

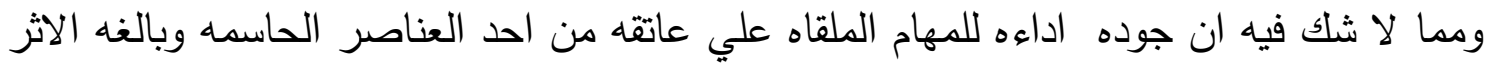
في تحسين مخرجات الجامعه وجودتها من خلال الطرائق والاستراتيجيات المعتمده في التدريس التهاه والتقويم وطبيعه العلاقه السائده بين الاستاذ وطلابه .

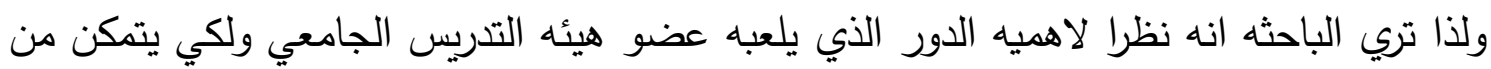

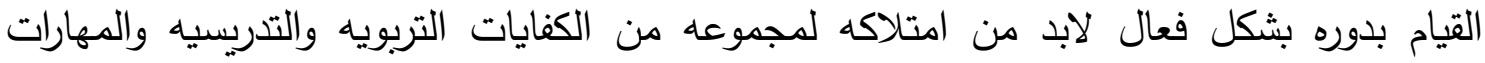

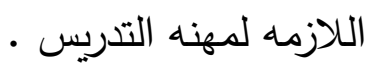
فالكفايات هي احدي الاستراتيجيات التربويه الحديثه للتدريس التي تعتمد توجها معلنا في تحديد

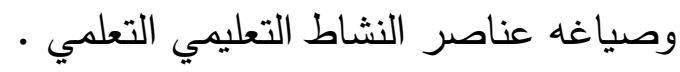

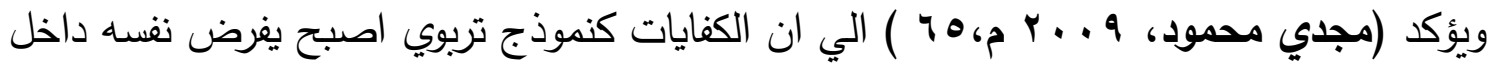
مختلف مجالات التربيه والتعليم بفعل قوه ملائمته لروح العصر ، خاصه وان هذا النموذج يساعد علي تكوين طلاب قادرين علي التكيف مع مختلف المستجدات العلميه والثقافيه والاقتصاديه

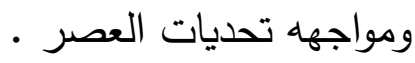


ويضيف (علي راثد ،ه . . . م، Y r ) الي ان نجاج العمليه التعليميه يعتمد بشكل كبير علي قدره عضو هيئه التدريس علي تجسيد خطه الدرس عمليا وهذا يتوقف علي مدي امتلاكه لمجموعه من الكفايات التربويه والتدريسيه التي تجعل خطته تتصف بالمرونه والفاعليه .

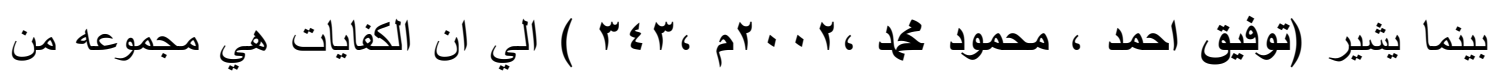
المهارات والمعارف والاتجاهات التي توجه سلوك التدريس لدي المعلم وتساعده في اداء عمله داخل القاعه او خارجها بمستوي معين من التمكن في الاداء باقل جهد ووقت وتكلفه.

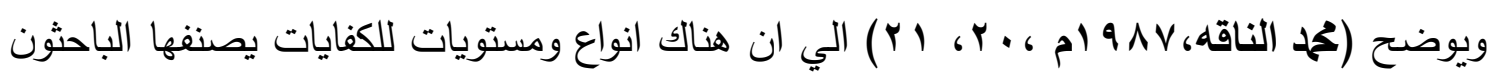
حسب المراحل والمواقف التدريسيه ، ورغم تداخلها وترابطها ، فهي تسعي في مجملها الي تحقيق الاهداف التعليميه في جوانبها المعرفيه والمهاريه والادائيه والتربويه فليس ثمه تصنيف مطلق.

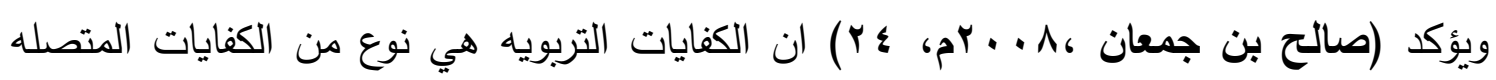
بالاستعدادات والميول والاتجاهات والقيم الاخلاقيه والمثل العليا ويمكن اشتقاقها من القيم الاخلاقيه والمبادئ السائده في اي نظام.

\section{مشكله البحث}

لاحظت الباحثه ان استخدام نمط" التعليم المدمج "بات ضرورة حتمية كأحد النظم التعليمية الحديثة، وهو الاتجاه الأنسب الأن لتوفير بيئة تعليمية تفاعلية تناسب احتياجات المتعلمين في حالات الطوارئ فى ظل التوجه العالمى إلى اعتماد الأدوات الرقمية في التعليم العالي في جميع أنحاء العالم والذي يؤدي بدوره الي رفع مستوي الطموح لديهم .

حيث يعدعضو هيئه التدري هو حجر الزاويه في العمليه التعليميه ويحتل الصداره بين العوامل التي يتوقف عليها نجاح التربيه في بلوغ غايتها علي اعتبار انه لا يمكن الفصل بين مسئوليات عضو هيئه التدريس والتغييرات الاساسيه التي تتم في المجتمع ،اذن لابد لعضو هيئه التدريس من كفايات تربويه وتدريسيه تؤمن توافقه المهني الذي يؤدي الي الشعور باتجاهات ايجابيه لدي الطالبات نحو التعليم المدمج وبالتالي يؤدي الي رفع مستوي طموحهم •

لذا رات الباحثه ان دن اهم مؤشرات الجوده الشامله في التعليم هو التركيز علي المتعلم والاهتمام بحاجاته ومتطلباته التعليميه والاجتماعيه والنفسيه لذا فان تقويم عضو هيئه التدريس عن طريق هيق طلابه اصدق المحكمات واكثرها ثباتا في عمله ومهاراته وما يلم من خبرات وممارسات تتعلق بمهنه التدريس والعمليه التربويه . 
ومن خلال مناقشة الباحثه لبعض الطالبات في ظل جائحه كورونا فقد أمكن استخلاص أن هناك بعض من المشكلات المرتبطة بالتعليم المدمج ،ومن خلال الدراسات السابقة والقراءات النظرية وفي حدود علم الباحثه قلة عدد الدراسات التى تربط بين الاتجاهات نحو التعليم المدمج والكفايات التربويه والتدريسيه لعضو هيئه التدريس وهو ما دفع الباحثه لمحاولة التعرف علي اتجاهات طالبات كليه التربيه الرياضيه بنات جامعه الزقازيق نحو التعليم المدمج وعلاقتها بمستوي الطموح لديهم والكفايات التربويه لاعضاء هيئه التدريس من وجهه نظرهم في ظل مستحدثات جائحه كورونا.

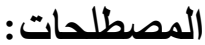

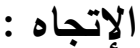

هو الموقف الذي يتخذه الفرد أو الإستجابة التي يبديها إزاء شئ معين أو حديث معين أو قضية معينة إما بالقبول أو الرفض أو المعارضة، نتيجة مروره بخبره معينه أو بحكم توافر ظروف أو الو شروط تتعلق بذلك الثئ أو الحدث أو القضية"( حسن شحاتة، زينب النجار ، س . . بم، 7 ( ). هى استجابات الطالبات او ميولهن نحو المعارف والخبرات المرتبطة بالتعليم المدمج وذلك من حيث تأييدهن اومعارضتهن لها طبقا للبيئة المحيطة بهن، أولمعتقداتهن وشعورهن نحوه . ( تعريف اجرائي ( ) التعليم المدمـج

هي استراتيجيه تعليميه تعلميه تعتمد علي الدمج بين التقنيات الحديثه في التعليم مع الاساليب التقليديه التي اعتادها اعضاء هيئه التدريس في تقديم المحتوي التعليمي لخلق بيئه تعليميه تعلميه فعاله بين عضو هيئه التدريس والطالبه بهدف تحقيق الاهداف التعليميه المنشوده بشكل افضل في ظل جائحه كورونا (تعريف اجرائي*) مستوى الطموح

هو مستوى الإنجاز الذى يتوقعه ويحدده الفرد لنفسة ويشعر من خلاله بأنه يستطيع تحقيق

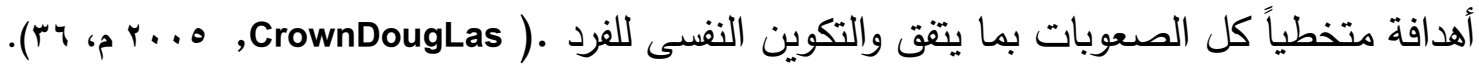


جميع المعارف والمهارات والقدرات التي يحتاجها المعلم اثناء الموقف التعليمي كما تشمل هذه الكفايات كل من شانه تحضير الطالبات واستثاره اهتمامهم بحتوي التعليم وطرائقه ونتائجه ومساعدتهم علي بلوغ النتائج المستهدفه الي اقصي ما تستسطيعه قدراتهم الخاصهه .

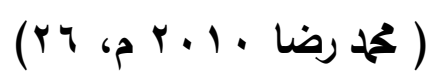

هي مجموعه من الممارسات التربويه والتدريسيه التي يقوم بها اعضاء هيئه التدريس في الموقف التعليمي لتمكينهم من مهامهم التعليميه داخل قاعات التدريس والمتمثله في الكفايات التاليه :كفايه التخطيط للتدريس ، كفايه تنفيذ الدرس ، كفايه استخدام الوسائل التعليميه ، كفايه اداره الصف ، كفايه التقويم (تعريف اجرائي*) |عضاء هيئه التدريس : هو كل من يقوم بالتدري في الكليه من حمله الدكتوراه ويساهم في تحقيق اهداف العمليه التعليميه (تعريف اجرائي") هدف البحث :

يهدف البحث الي التعرف علي العلاقه بين اتجاهات طالبات كليه التربيه الرياضيه بنات جامعه الزقازيق نحو التعليم المدمج و ومستوي الطموح لديهم و الكفايات التربويه لاعضاء هيئه التدريس من وجهه نظرهم في ظل مستحدثات جائحه كورونا. فروض البحث:

ا - توجد علاقة بين الاتجاهات نحو التعليم المدمج ومستوي الطموح لدى طالبات كليه التربيه الرياضيه بنات جامعه الزقازيق. r- توجد علاقة بين الاتجاهات نحو التعليم المدمج والكفايات التربويه لاعضاء هيئه التّريس لاى طالبات كليه التربيه الرياضيه بنات جامعه الزقازيق. ז- توجد علاقة بين مستوى الطموح والكفايات التربويه لاعضاء هيئه التدريس لدى طالبات كليه التربيه الرياضيه بنات جامعه الزقازيق. الاسرات المرجعيه : (المبات ا- دراسه نهاله سيد أحمد" •r • rم" تهذف الدراسد الي التعرف علي تاثير استخدام التعليم المدمج (الموقع الاكتروني -التعلم التعاوني ( علي مستوي الاداء المهاري لسباحه الزحف علي البطن 
واستخدمت الباحثة المنهج التجريىى لثلاث مجموعات، (مجموعتين تجريبيتين ومجموعة ضابطة) علي عينه قوامها (^^) طالب بنادى الوليد الرياضى بميت غمر وتم تقسيمهم إلى ثلاث مجموعات متساوية قوام كل منهما (·) طلاب، وتم إستخدام التعليم المدمج للمجموعة الأولى والتعليم الالكترونى للمجموعة الثانية، وأسلوب الأوامر للمجموعة الثالثة، كما تم إختيار (^) طلاب لإجراء التجربة الإستطلاعية عليهم وقد توصلت اهم النتائج الي فاعليه التعليم المدمج علي مستوي الاداء المهاري للطلاب في مهاره سباحه الزحف علي البطن .

r- دراسه رامي تحمد تحمد" 1 • بrم" : تهدف الدراسه الي التعرف علي تقويم مقرر طرق تدريس التربية الرياضية في ضوء متطلبات الكفايات التدريية للطالب المعلم ببعض كليات التربية الرياضية بجمهورية مصر العربية،استخدام الباحث المنهج الوصفي علي عينه قوامها م77هالب وطالبه وقد توصلت اهم النتائج الي عدم وجود فروق دالة احصائياً بين الطلاب والطالبات في الكفاءات التدريسية ( تخطيط الدرس، وتقويم الدرس). وجود فروق دالة احصائياً بين الطلاب و الطالبات في الكفاءات التدريسية( أهداف الدرس ، تنفيذ الدرس ، تقويم الدرس، والدرجة الكلية) لصالح الطلاب

r-دراسه ماجد عاطف إبراهيم "9 1 • بم" تهدف الدراسة الي التعرُّف علي مدى فاعلية برنامج تدريبي مقترح في تتمية كفايات تدريس اللغة العربية لدى الطلبة المعلمين / قسم اللغة العربية بجامعة الأزهر بغزة في ضوء احتياجاتهم التدريسيه، واستخدم الباحث المنهج التجريبي علي عينه قوامها ( • ب) طالباً وطالبةً وقد تم إعداد قائمة بالاحتياجات التدريسيه اللازمة للطلبة المعلمين قمم اللغة العربية بجامعة الأزهر بغزة ، وكذللك إعداد قائمة بالكفايات التدريسية الواجب توفرها لدى الطلبة المعلمين قسم اللغة العربية بجامعة الأزهر بغزة وقد توصلت اهم النتائج الي فاعلية البرنامج التدريبي في تتمية كفايات التدريس بشقَّيها المعرفي والأدائي لدى مجموعة الدراسة.

ع -دراسه محمد شاكر تركي "9 1 • بم" تهدف الدراسه الي التعرف علي تاثير تتمية الأداء التدريسي لدى معلمي الدراسات الاجتماعية بالمرحلة الأساسية بدولة الأردن من خلال برنامج تدربي وسائطي تفاعلي قائم على الكفايات التدريسية والاتجاه نحوه, استخدم الباحث المنهج التجريبي علي عينه قوامها(· r) معلماً بالمرحلة الأساسية بالأردن وقد توصلت اهم النتائج الي يوجد فرق دال إحصائياً عند مستوى (1 ( . • ) بين متوسطي رتب درجات معلمي مجموعة البحث في اختبار الأداء التدريسي قبلياً وبعدياً, والدرجة الكلية للاختبار لصالح التطبيق البعدي و يوجد فرق دال إحصائياً 
عند مستوى (1 +. • ) بين متوسطي رتب درجات معلمي مجموعة البحث في مقياس الاتجاه قبلياً وبعدياً لصالح التطبيق البعدي.

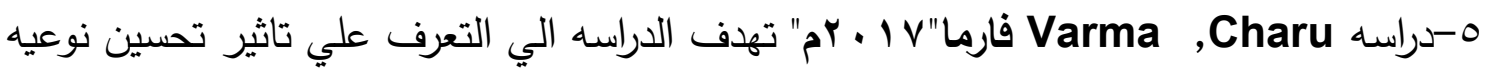
التعليم الابتدائي عن طريق مراقبه الكفايات التدريسيه لدي معلمي التعليم الشامل وقد استخدمت الباحثه المنهج الوصفي علي عينه قوامها Y M r معلم ومعلمه وقد توصلت اهم النتائج الي ضروره تدريب المعلمين علي استخدام طرائق تدريس قائمه علي حاجات المتعلم وان يوظفوا ماتيسر لهم من بنيه تحتيه في مؤسساتهم التربويه والعمل علي اخضاع المعلمين المبتدئي الي برامج تدرببيه اثثاء خدمتهم

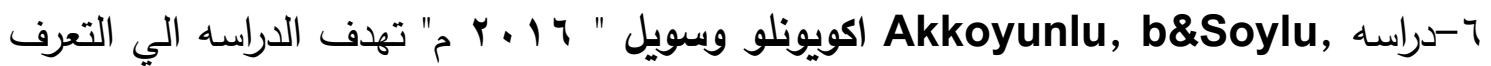
علي تاثير تقصي وجهه نظر المتعلمين في بيئه التعلم المدمج واستخدم الباحثان المنهج الوصفي علي عينه قوامها ـ ج طالبا من طلاب قسم الحاسوب وقد توصلت اهم النائج الي وجود اتجاهات ايجابيه لدي الطلاب نحو التعليم المدمج ووجود اثر لطريقه التعليم المدمج في التحصيل الدراسي للطالاب

V-دراسة دلال يوسفى " 1 1 • بم" تهدف الدراسه إلى التعرف على تاثير فاعلية برنامج إشادى على تقدير الذات ومستوى الطموح الأكاديمى لدى تلاميذ المرحلة الثانوية " واستخدمت الباحثه المنهج التجريبى ، علي عينة قوامها ( . . ع) طالبة وطالبة، وكانت أهم النتائج أنه توجد علاقة إرتباطية إيجابية دالة إحصائيا بين تقدير الذات ومستوى الطموح •

1-دراسة هبة الله علي رشوان "ه ا • بم" تهدف الدراسه الي التعرف علي تأثير دراسة مقرر تاريخ وفلسفة التربية الرياضية على تتمية الإتجاهات الفلسفية الإيجابية نحو ممارسة النشاط البدني لطالبات كلية التربية الرياضية بنات جامعة الزقازيق ، استخدمت الباحثة المنهج التجربیى،عي عينة قوامها (Y^ᄉ) طالبة، وكانت أهم النتائج أن العوامل الثقافية والوجدانية والسلوكية كان لها دور كبير فى تعديل إتجاهات الطالبات نحو التربية الرياضية , وجود فروق دالة إحصائياً بين الاتجاهات الفلسفية نحو ممارسة النشاط البدنى قبل وبعد دراسة مقرر تاريخ وفلسفة التربية الرياضية ولصالح القياس البعدى.

9-دراسة كارلسون Carlson"ه 1 • ب م" تهدف الدراسه الي التعرف علي اتجاهات طلاب المرحلة الثانوية نحو التربية الرياضية ومعرفة العوامل المؤثرة في تكوين تلك الاتجاهات،واستخدم الباحث 
المنهج الوصفي ، علي عينة قوامها(م) طالباً وطالبة، وكانت أهم النتائج أن العوامل الثقافية والاجتماعية من أكثر العوامل تأثيراً على تكوين الاتجاهات لدى الطلبة، أن الأسرة والإعلام ومستوى الأداء المهاري لدى الطلبة والأصدقاء والخبرة السابقة في الممارسة الرياضية جميعها هامة في تحديد اتجاهات الطلبة نحو التربية الرياضية وأن مفهوم الطلبة نحو ممارسه التربية الرياضية من أجل المتعة ، وأن التربية الرياضية محدودة الأهداف وتقتصر على إعداد الرياضيين.

• ا-دراسة دعاء كمال عحمد "Y I • م" تهدف الاراسه إلى التعرف على تأثير إستخدام إستراتيجية

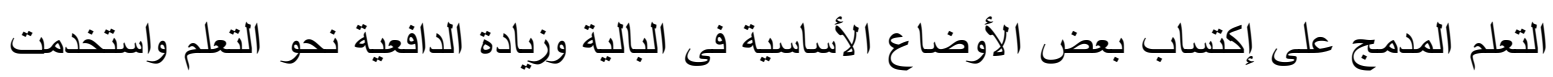
الباحثة المنهج التجريبى علي عينة قوامها (0 1 ) طالبة ، وقد توصلت أهم النتائج أن أستخدام الأساليب الحديثة فى التدريس أدت إلى زيادة الدافعية نحو التعلم , وأن زيادة الدافعية أدى إلى تحسين مستوى ولى ولى الأداء المهارى.

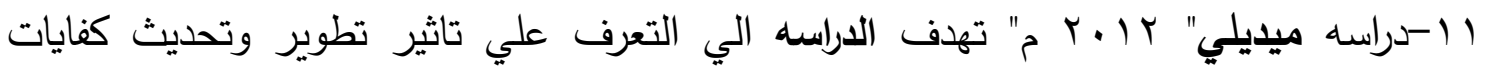
المعلمين من اجل تحسين وتطوير اداء المعلمين في ولايه ميتشجن بالولايات المتحده واستخدم الباحث المنهج الوصفي علي عينه قوامها ror من الخبراء التعليمين وقد توصلت اهم النتائج الي ان هناك كفايات جديده قد ظهرت واضيفت من خلال هذه المصفوفه المكونه من ع ع أكفايه مقسمه الي با مجموعه وان الكفايات قد تم حذفها او تغيرها بناء علي اراء الخبراء والنتائج التي ظهرت وقد تم اعاده ترتيب الكفايات علي حسب الاهميه

r ا- دراسه هدى عبدالحميد عبدالوهاب "r ا • rم" تهدف الدراسه إلى التعرف علي أثر تتمية الإيجابية على الحالة النفسية العامة ومستوى الطموح لطالبات الفرقة الأولى بكلية التربية الرياضية بنات جامعة الزقازيق واستخدمت الباحثه المنهج التجريبى ، علي عينة قوامها (مبr) طالبة ، وكانت أهم النتائج أنه توجد علاقة إرتباطية إيجابية دالة إحصائياً بين الإيجابية وكلاً من الحالة النفسية العامة

ومستوى الطموح. rا -دراسه دينغ وهافانغ "9 ، . بrم" تهدف الدراسه الي تقصي اثر تجارب المحاكاه بالحاسوب في استكشاف الطلاب تعلم انكسار الضوء في الصين واستخدم الباحثان المنهج التجريبي علي عينه قوامها (ع 7) طالبا من طلبه الكليه واعد الباحثان بيئه التعلم بالمحاكاه عن طريق بيئات عرض قويه وداعمه وقد توصلت اهم النتائج الي تفوق المجموعه التي درست التجربه بالمحاكاه الافتراضيه في مهارات البحث وتحسين القدرات الاستكشافيه 
ع ا-دراسه ريزون وستافكين" ه . . ץ" تهذف الدراسه الي استطلاع نموذج التعليم المدمج " الهجين " نتائج الطلبه في دورات مختلفه الاشكال واستخدم الباحثان المنهج الوصفي غلي عينه قوامها ب +ء طالبا وطالبه في السنه الثانيه الجامعيه وقد توصلت اهم النتائج الي تفوق افراد المجموعه التي درست باسلوب التعليم المدمج في التحصيل واتجاهاتهم اكثر ايجابيه من

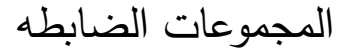

\section{اجراءات البحث أولاً: منهج البحث:}

استخدمت الباحثة المنهج الوصفى بالطريقة المسحية وذلك لملائمته لطبيعة هذه الدراسة.

ثانياً : مجتمع البحث: يتكون مجتمع البحث من طالبات الفرقه الرابعه لكليه التربيه الرياضيه بنات جامعه الزقازيق في

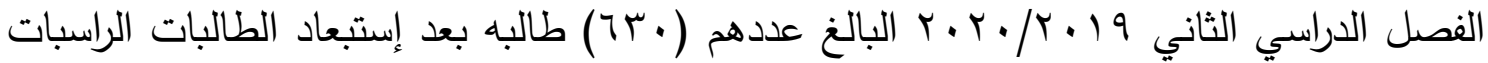
وقامت الباحثة بايجاد إعتدالية توزيع مجتمع البحث فى المتغيرات والجدول الأتى يوضح ذلك

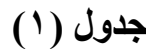

توصيف مجتمع البحث فى المتغيرات قيد البحث

$(\pi+=\dot{0})$

\begin{tabular}{|c|c|c|c|c|c|c|}
\hline الإلتواء & الإنحراف & الوسيط & الحستوسط & القياس & المتغيرات & r \\
\hline 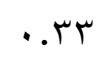 & $\cdot . \leqslant 0$ & $r$. & $r \ldots .0$ & 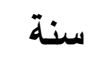 & العمر الزمني & 1 \\
\hline 1.14 & T.Tะ & $1 \ldots$ & 1.1 .1 & درجة & القدرة العقلية & r \\
\hline $1.10-$ & $1 . r 0$ & 71 & $7 \cdot . \leqslant \wedge$ & درجة & الاتجاهات النفسية نحو التعليم المدمج & $r$ \\
\hline 1.17 & r.IT & tr & $T Y . \wedge T$ & درجة & مستوي الطموح & $\varepsilon$ \\
\hline 1.17 & t.IT & $1 \cdot r$ & (-T & درجة & الكفايات التربويه لاعضاء هيئه التدريس & ० \\
\hline
\end{tabular}

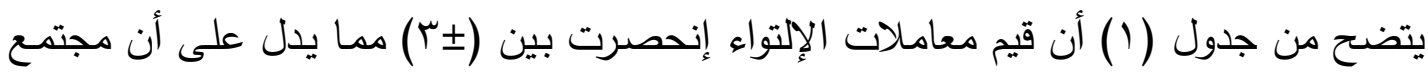
البحث معتدل اعتدالا طبيعياً فى هذه المتغيرات المقاسة قيد البحث

:ثالثا : عينة البحث : أبث بعد أن تم إيجاد إعتدالية مجتمع البحث قامت الباحثة بتحديد عينة البحث بالطريقة العمدية وهن الطالبات الحاصلات على أقل الدرجات فى مقياس الإتجاهات نحو التعليم المدمج ومستوي الطموح 
والبالغ عددهن ( • عاطالبة ). تم سحب (0 لطالبة ) بطريقة عشوائية كعينة إستطلاعية فأصبحت عينة البحث الأساسية (0 7 بطالبة ). أدوات ووسائل جمع البيانات: الب • المقابلات الشخصية مع خبراء في مجال علم النفس : ملحق( (1)

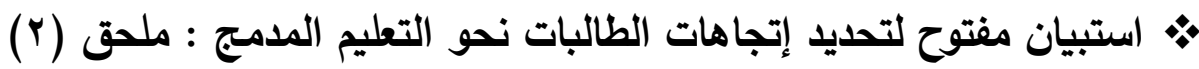
• إختبار القدرة العقلية (الأكاء) إعداد فاروق عبد الفتاح (q . . rم) ملحق (r ) ) استخدمته الباحثه لايجاد إعتدالية التوزيع التكرارى لمجتمع البحث ويقيس هذا الاختبار معامل الذكاء ولقد طبق فى العديد من الدراسات العربية المماثلة وكانت معاملاته العلمية عالية. • مقياس الإتجاهات نحو التعليم المدمج لطالبات كليه التربيه الرياضيه بنات جامعه

الزقازيق (إعداد الباحثه). ملحق (^)

فى ضوء أهداف البحث وطبيعته ونظرا لقلة وجود مقياس لقياس الاتجاهات نحو التعليم المدمج حديث يتناسب مع طبيعة العينة ومتغيرات البحث ، فقد قامت الباحثة ببناء المقياس والهدف منه التعرف على الاتجاهات نحو التعليم المدمج لطالبات كليه التربيه الرياضيه بنات جامعه الزقازيق ، وبعد أن تم الاطلاع على الكتب والمراجع العلمية والاطر النظرية والدراسات السابقة والبحوث المرتبطة وإستطلاع رأى السادة الخبراء ملحق (1) بموضوع الاتجاهات نحو التعليم المدمج. قامت الباحثة ببناء مقياس الاتجاهات نحو التعليم المدمج مسترشدة بالخطوات الآتية: - 20 - n

• تحديد الابعاد الأساسية للمقياس : تم وضع الأبعاد في صورتها المبدئية في استمارة ملحق (0)، ثم تم عرضها علي السادة الخبراء المتخصصين في مجال علم اصول التربيه و النفس الرياضي والبحث العلمى ملحق(1) والجدول رقم (Y) يوضتح أراء السادة الخبراء حول أبعاد

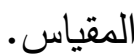




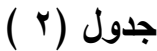

آراء الخبراء حول تحديد الأبعاد الرئيسية لمقياس الاتجاهات

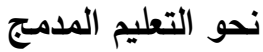

$1 \cdot=\dot{0}$

\begin{tabular}{|c|c|c|c|c|}
\hline |(النسبة المئوية & |غيرموافق & |موافق & | الأبعاد & م \\
\hline$\% 1 \ldots$ & $\cdot$ & 1. & |البعد المعرفى & 1 \\
\hline$\% 1 \ldots$ & $\cdot$ & 1. & |البعد التربوي & r \\
\hline$\% 1 \ldots$ & . & 1. & |البعد الاجتماعى & $r$ \\
\hline$\% \wedge$. & $r$ & $\wedge$ & |البعد الانفعالي & $\varepsilon$ \\
\hline$\% \wedge$. & $r$ & $\wedge$ & (البعد السلوكي & 0 \\
\hline$\% 4$ & $\varepsilon$ & 7 & |البعد الإدراكي & 1 \\
\hline
\end{tabular}

يوضح جدول (Y) آراء الخبراء في تحديد الأبعاد الرئيسية لمقياس الاتجاهات نحو التعليم المدمج

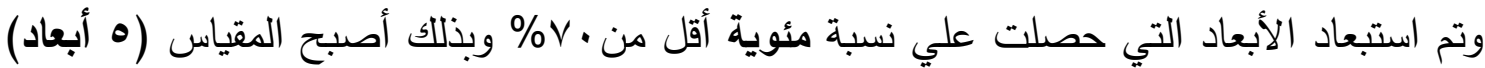

تحديد العبارات الخاصة بكل بعد من أبعاد المقياس وعرضها علي السادة الخبراء.بعد التوصل لابعاد المقياس قامت الباحثة بإعداد العبارات المناسبة لكل بعد وقد راعت فيها :

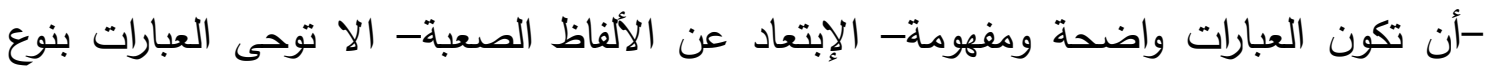
الإستجابة- عدم الإزدواجية للعبارة- أن تقيس العبارات جانب من جوانب البعد الذى تتتمى إلية وقد

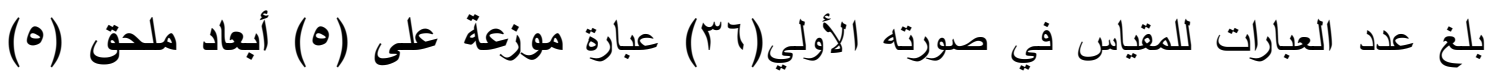

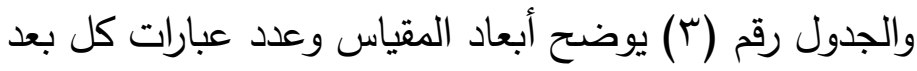

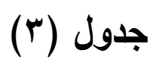

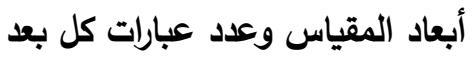

$1 \cdot=\dot{0}$

\begin{tabular}{|c|c|c|}
\hline عددالعبارات & الأبعاد & 5 \\
\hline 9 & البعد المعرفى & 1 \\
\hline$\wedge$ & البعد التربوي & r \\
\hline$v$ & البعد الاجتماعى & $\mu$ \\
\hline 7 & البعد الانفعالي & $\varepsilon$ \\
\hline 7 & البعد السلوكي & $\bullet$ \\
\hline rq & \multicolumn{2}{|c|}{ العدد الإجمالى للعبارات } \\
\hline
\end{tabular}




$$
\text { يوضح جدول رقم (r) الابعاد وعدد عبارات كل بعد والعدد الكلى للمقياس. }
$$

ثم قامت الباحثة بتوزيع المقياس في صورته الأولى على السادة الخبراء للوقوف على مدى انتماء كل عبارة للبعد الذى تتتمى اليه فى المقياس وكذلك إضافة أو حذف أو تعديل صياغة ایى عبارات وكذلك لتحديد مدى انتماء هذه العبارات للبعد الخاص بها وتحديد ميزان التقدير الخاص بالمقياس. - المعالجات الإحصائية لاراء الخبراء على العبارات الخاصة بكل بعد :- عن طريق التقدير الكمي والتقدير الكيفي للعبارات ملحق( ()، ويوضح جدول (ع) نتائج تعديل السادة الخبراء على المقياس.

\section{جدول (飞)}

استطلاع رأي الخبراء في أبعاد وعبارات المقياس

$$
1 \cdot=\dot{0}
$$

\begin{tabular}{|c|c|c|c|c|c|}
\hline العدد النهائي للعبارات & عدد العبارات التى تم & تعديل صياغتها ألعبارات التى تم & أرقام العبارات التى تم & عدد عبارات & أبعاد أبع \\
\hline 9 & 9 & O ، & $(\varepsilon)$ & 9 & البعد المعرفى \\
\hline$v$ & - & $V \quad 6061$ & $\varepsilon$ & $\wedge$ & البعد التربوي \\
\hline 7 & . & $V$ ، $\{$, & 0 & $v$ & البعد الاجتماعى \\
\hline 7 & - & $\varepsilon$ & - & 7 & البعد الانفعالي \\
\hline 7 & 9 & . & 1 & 7 & البعد السلوكي \\
\hline ६ & \multicolumn{4}{|c|}{ q } & المجموع \\
\hline
\end{tabular}

إعداد المقياس لتطبيقه على العينة الاستطلاعية: بعد أن تم إعداد المقياس في صورته الثانية وعدد عباراته (؟ب)عباره موزعة على(0) أبعاد ملحق(V)، قامت الباحثة بتوزيع عباراته عشوائيا ملحق (^) لكى يتم تطبيقه يوم الثلاثاء الموافق

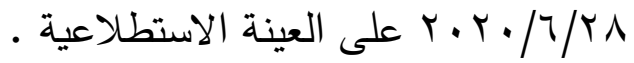




\section{المجلة العامبة لعلوه وفانون الرإضة}

\section{جدول (•) (0)}

التوزيع العشوائى لعبارات المقياس للعينة الاستطلاعية (0)

\begin{tabular}{|c|c|c|}
\hline أرقام العبارات موزعة عشوائياً & عدد العبارات & 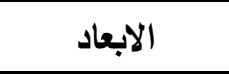 \\
\hline$r \varepsilon-r r-r 1-r q-Y 1-19-11-q-1$ & 9 & البعد المعرفى \\
\hline$r r-r V-r r-1 V-1 r-V-r$ & $\mathrm{v}$ & البعد التربوي \\
\hline$r \Lambda-r r-1 \Lambda-1 r-\Lambda-r$ & 1 & البعد الاجتماعى \\
\hline$r q-r \leq-1 q-1 \leq-q-\varepsilon$ & 9 & البعد الانفعالي \\
\hline r. YO-Y. - - $0-1 \cdot-0$ & 1 & البعد السلوكي \\
\hline
\end{tabular}

حساب المعاملات العلمية لمقياس الاتجاهات نحو التعليم المدمج

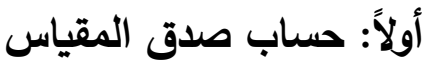

1- صدق المحكمين : قامت الباحثة بعرض أبعاد المقياس وعبارات كل بُعد على السادة

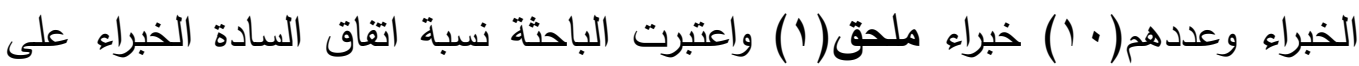
المقياس معياراً لصدقه r - صدق الاتساق الداخلي لعبارات وأبعاد المقياس: قامت الباحثة بحساب الصدق وذلك بحساب قيمة معامل الارتباط بين درجة كل عبارة على حده والدرجة الكلية للبعد الذى تتنمى إليه ودرجة كل بعد والدرجة الكلية للمقياس على عينة الدراسة

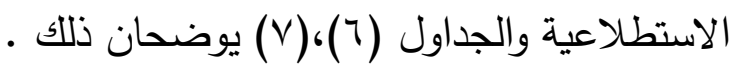




\section{جدول (†)}

معامل الارتباط بين درجة كل عبارة على حدة واللدرجة الكلية لكل بعد من أبعاد

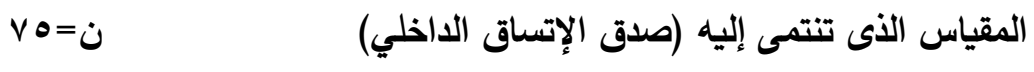

\begin{tabular}{|c|c|c|c|c|c|}
\hline |البعد السلوكي & البعد الانفعالي & |لبعد الاجتماعي | & البعد التربوي & البعدالمعرفى & \\
\hline$* . .0 \leqslant \mu$ & $* \ldots \varepsilon r \varepsilon$ & $* . . \leqslant \leq \varepsilon$ & $*$ * . Tr & $* .7 \leq 7$ & 1 \\
\hline *. . . & $* . \leqslant \odot V$ & *. . & * . . \&VI & $* \ldots \leqslant 01$ & $r$ \\
\hline$* . . \diamond \wedge 1$ & $* . . \Delta r r$ & $* . . \vee V Y$ & $* . .00 \leqslant$ & $* . . \mu \wedge$. & $r$ \\
\hline$* . . \Delta \vee \mu$ & $* . . \varepsilon q r$ & $* . . \varepsilon \vee Y$ & $* . .7 \mu \mathrm{V}$ & $* . . \diamond \wedge r$ & $\varepsilon$ \\
\hline$* . . \varepsilon \wedge \mu$ & $* . \varepsilon \wedge \neg$ & $* .7 \wedge 0$ & $* . . \varepsilon \cdot r$ & $* \ldots \varepsilon r r$ & 0 \\
\hline *. . . & $* . . \diamond \wedge \wedge$ & $* . . \diamond \wedge \mathrm{V}$ & $* .01 \wedge$ & $* \ldots \vee \vee \neg$ & 7 \\
\hline \multirow[t]{4}{*}{ *. . . } & $* .7 Y_{1}$ & $* .70$. & $* .07$ & *. . . r r & $v$ \\
\hline & $* . . \varepsilon q$. & $* . . \leqslant \varepsilon \varepsilon$ & *. . . & $* .7 \leq \Lambda$ & $\Lambda$ \\
\hline & & $* . .7 \leq r$ & $* . .00 \leqslant$ & $* \ldots \leqslant V$ & 9 \\
\hline & & $* . \Delta \mu^{*}$ & $* .711$ & & 1. \\
\hline
\end{tabular}

دلالة معامل الإرتباط عند مستوي (0. . . = = rr.

يتضح من جدول (7) وجود ارتباط دال احصائياً بين درجة كل عبارة والبعد الذى تتتمي اليه العبارة ، كما يتضح أن جميع معاملات الارتباط دالة عند مستوي الدلالة ه . . . وهذا يكون مؤشراً لصدق البناء الداخلى لعبارات المقياس المقترح.

\section{جدول (v)}

قيم معاملات الارتباط بين درجات كل بعد والدرجة الكلية لمقياس الاتجاهات نحو التعليم المدمج ( الاتساق الداخلي لابعاد المقياس)

$V \theta=\dot{0}$

\begin{tabular}{|c|c|c|}
\hline معامل الارتباط & 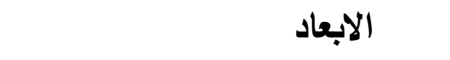 & م \\
\hline$* . . \wedge \mathrm{r}$ & البعدالمعرفى & 1 \\
\hline$* . .7 \bullet r$ & البعد التربوي & $r$ \\
\hline$* . .77 \%$ & البعد الاجتماعي & r \\
\hline$* . .0 Y \varepsilon$ & البعدالانفعالي & $\varepsilon$ \\
\hline$* . . \vee \vee \bullet$ & البعد السلوكي & 0 \\
\hline$* .79 V$ & ل الاتجاهات نحو التعليم المدمـج & \\
\hline
\end{tabular}

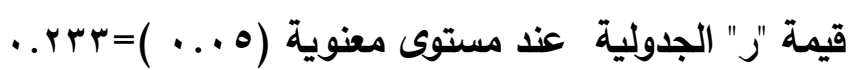


يتضح من جدول (V) أن قيم معاملات الارتباط بين درجات كل بعد والدرجة الكلية للمقياس

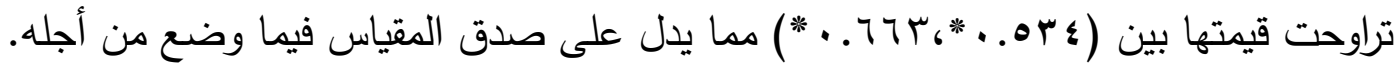
حساب ثبات مقياس الاتجاهات: معامل الثبات : قامت الباحثة بحساب معامل ثبات المقياس وذللك عن طريق "معامل ألفاكرونباخ" ، وذلك بمعالجة بيانات العينة الاستطلاعية ، والجدول رقم (^) يوضح الاتي: (^) جدول (1) معامل الثبات لمقياس الاتجاهات نحو التعليم المدمج قيدالبحث

$V \Delta=\dot{0}$

\begin{tabular}{|c|c|c|}
\hline معامل ألفاكرونباخ & أبعاد المقياس & م \\
\hline$. .7 \leq r$ & البعدالمعرفى & 1 \\
\hline $.0 \leq r$ & البعد التربوي & r \\
\hline $.7 \leq \leq$ & البعد الاجتماعي & $r$ \\
\hline $.90 \leq$ & البعدالانفعالي & \{ \\
\hline$\because V Y O$ & البعد السلوكي & 0 \\
\hline
\end{tabular}

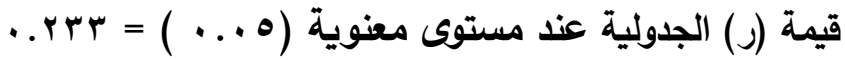

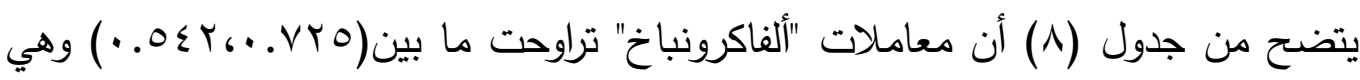
معاملات ارتباط دالة إحصائياً مما يدل على أن المقياس قيد البحث ذو معامل ثبات عالي. طريقة تصحيح مقياس الاتجاهات نحو التعليم المدمج:

تحسب درجات استجابات المقياس على ميزان تقدير ثلاثي (نعم ، أحيانا ، مطلقا) درجاتهم (r r - ( ) على التوالي للعبارات ، وبذلك تكون الدرجة الصغرى للمقياس(ع ب) و الوسطى (1^) و العظمى (99 (1) درجة وتعبر الدرجة المرتفعة على المقياس على إتجاهات مرتفعة نحو التعليم المدمج والعكس

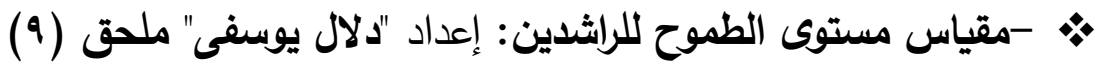
ويحتوى على (·r) سؤال تندرج تحت (ع) أبعاد رئيسية (القدرة على وضع الأهداف ، المثابرة ،التفاؤل ،القدرة على تحمل المسئولية ) وتدل الدرجة المرتفعة على زيادة مستوى الطموح والعكس، وقد حقق المقياس معاملات صدق وثبات عالية فى العديد من الدراسات والأبحاث -حساب المعاملات العلمية لمقياس مستوى الطموح:-أولاً: حساب صدق المقياس 
-صدق الاتساق الداخلي لعبارات وأبعاد المقياس: قامت الباحثه بحساب صدق المقياس وذللك بحساب قيمة معامل الارتباط بين درجة كل عبارة على حده والدرجة الكلية للبعد الذي تتتمي إليه ، ودرجة كل بعد والدرجة الكلية للمقياس على عينة الدراسة الاستطلاعية والجدولين (9)، ( • ( ) يوضحان ذلك.

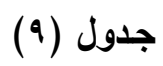

معامل الارتباط بين درجة كل عبارة على حدة والارجة الكلية لكل بعد من أبعاد المقياس الذى

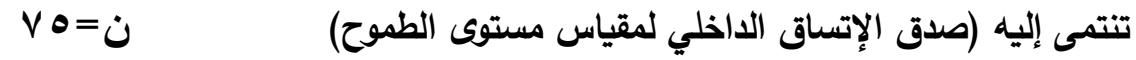

\begin{tabular}{|c|c|c|c|c|}
\hline القدرة على تحمل المسئولية & التفأول & المثابرة & القدرة على وضع الأهداف & $\begin{array}{l}\text { العبارات الابعاد } \\
\text { الاد }\end{array}$ \\
\hline *. . 11 . & $* . .00 \mathrm{~V}$ & $* \ldots \varepsilon \cdot V$ & * . . $\leqslant \leqslant 0$ & 1 \\
\hline$* \ldots \leq \leqslant 9$ & *. . Y Y & $* \ldots$. . & $* . .0 \leq \leq$ & r \\
\hline$*$ *.7r & $* . .700$ & $* \ldots \wedge$. . & $* . . r . r$ & $r$ \\
\hline *. . Or & *. . $\leqslant 74$ & * . . Tr & * . . \^॰ & $\varepsilon$ \\
\hline$* \ldots \leqslant \diamond \wedge$ & $* \ldots \wedge$ & *.. ^ & * . . & 0 \\
\hline *. . TV & $* . .079$ & $* \ldots$ & * . . TV0 & 7 \\
\hline$* \ldots$ & $*$ * . I Y & $*$ * . $\leqslant$ Or & צ ש . • & $v$ \\
\hline$*$. . $\{9 \vee$ & *.. . & & & $\wedge$ \\
\hline
\end{tabular}

يتضح من جدول (9) أن معاملات الارتباط بين كل عبارة والدرجة الكلية للبعد دالة إحصائيا عند مستوى (0 . . ) مما يدل على صدق المقياس فيما وضع من أجله.

جدول (1.)

قيم معاملات الارتباط بين درجات كل بعد والدرجة الكلية لمقياس مستوى الطموح

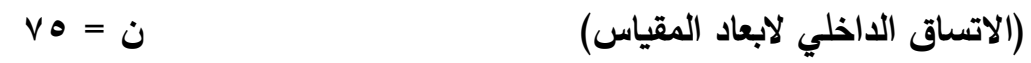

\begin{tabular}{|c|c|c|c|c|}
\hline 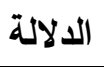 & قيمة "ر" & عدد العبارات & الابعاد & م \\
\hline 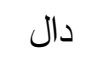 & $* . .7 V T$ & v & القدرة على وضع الأهداف & 1 \\
\hline 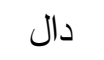 & *.0T1 & $v$ & المثابرة & $r$ \\
\hline 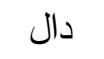 & $* .70 Y$ & $\wedge$ & التفأول & r \\
\hline 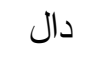 & $* .07 r$ & $\wedge$ & القدرة على تحمل المسئولية & $\varepsilon$ \\
\hline 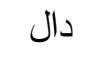 & $* . .0 \mathrm{VT}$ & r. & المجموع & \\
\hline
\end{tabular}




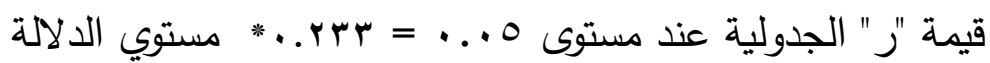
يتضح من جدول(• (1) أن قيم معاملات الارتباط بين درجات كل بعد والدرجة الكلية للمقياس

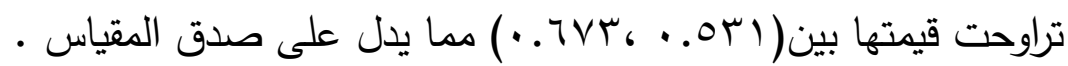
-ثانياً:حساب ثبات المقياس: الإيجاد معامل ثبات أبعاد المقياس وعددهم(§)أبعاد بعباراتهم وقامت الباحثة باستخدام"طريقة "ألفاكرونباخ Alpha"، وجدول( ( ) يوضح ذلك.

جدول (11)

الثبات"بالتجزئة النصفية"و" معامل ألفاكرونباخ "لأبعاد مقياس مستوى الطموح $v \otimes=\dot{0}$

\begin{tabular}{|c|c|c|c|}
\hline معالج ألفا كرونباخ & عدد العبارات & | الابعاد & م \\
\hline *. . VYr & $v$ & القدرة على وضع الأهداف & 1 \\
\hline$* . .7 \leqslant V$ & V & المثابرة & r \\
\hline$* .071$ & $\wedge$ & التفأول & $r$ \\
\hline *. . . & $\wedge$ & القدرة على تحمل المسئولية & $\varepsilon$ \\
\hline$* .0 \leqslant$. & $r$ & \multicolumn{2}{|c|}{ المجموع } \\
\hline
\end{tabular}

قيمة "ر" الجدولية عند مستوى 0 . . = بسץ..."مستوى الدلالة

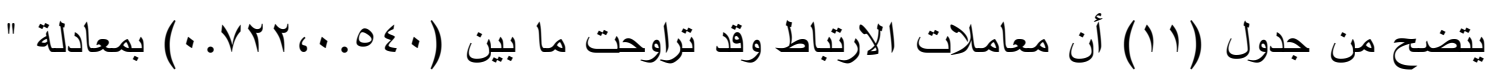
ألفا كرونباخ " مما يدل على أن المقياس ذو معامل ثبات عالي.

• مقياس الكفايات التربويه لاعضاء هيئه التدريس من وجهه نظر الطالبات (إعداد الباحثه). ملحق (ع (1) فى ضوء أهداف البحث وطبيعته ونظرا لقلة وجود مقياس لقياس الكفايات التربويه لاعضاء هيئه التدريس من وجهه نظر الطالبات يتناسب مع طبيعة العينة ومتغيرات البحث ، قامت الباحثة ببناء مقياس والهدف منه التعرف على الكفايات التربويه لاعضاء هيئه التدريس من وجهه نظر الطالبات ، وبعد أن تم الاطلاع على الكتب والمراجع العلمية والاطر النظرية والدراسات المرجعيه والبحوث المرتبطة وإستطلاع رأى السادة الخبراء ملحق (1) بالكفايات التربويه لاعضاء هيئه التدريس من 
وجهه نظر الطالبات. قامت الباحثة ببناء مقياس الكفايات التربويه لاعضاء هيئه التدريس من وجهه نظر الطالبات مسترشدة بالخطوات الآتية:

تحديد الابعاد الأساسية للمقياس : تم وضع الأبعاد في صورتها المبدئية في استمارة ملحق ( ( 1)، ثم تم عرضها علي السادة الخبراء المتخصصين في مجال علم اصول التربيه و النفس الرياضي والبحث العلمى ملحق( (1) والجدول رقم (Y I) يوضح أراء السادة الخبراء حول أبعاد المقياس.

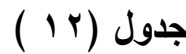

آراء الخبراء حول تحديد الأبعاد الرئيسية لمقياس الكفايات التربويه لاعضاء هيئه التدريس من وجهه نظر الطالبات

\begin{tabular}{|c|c|c|c|c|}
\hline النسبة المئوية & غيرموافق & 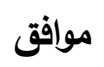 & 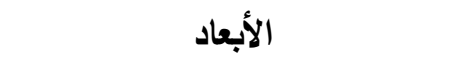 & b \\
\hline$\% 1 \ldots$ & . & 1. & كفايه التخطيط للمحاضره & 1 \\
\hline$\% 1 \ldots$ & - & 1. & كفايه تنفيذ المحاضره & r \\
\hline$\% 1 \ldots$ & - & 1. & كفايه اداره المحاضره & r \\
\hline$\% \wedge$. & r & $\wedge$ & كفايه استخدام الوسائل التعليميه & $\varepsilon$ \\
\hline$\% \wedge$. & r & $\wedge$ & كفايه التقويم & 0 \\
\hline$\% 1 \ldots$ & . & 1. & كفايه الجانب التربوي او الوجداني & 7 \\
\hline
\end{tabular}

يوضح جدول (Y I) آراء الخبراء في تحديد الأبعاد الرئيسية لمقياس الكفايات التربويه لاعضاء هيئه التدريس من وجهه نظر الطالبات ويتضح ان الاراء تراوحت مابين · مالي .. 1 \% وقد ارتضت الباحثه بهذه النسب ولم تستبعد اي بعد وبذلك يكون ابعاد المقياس (ه أبعاد) . تحديد العبارات الخاصة بكل بعد من أبعاد المقياس وعرضها علي السادة الخبراء بعد التوصل لابعاد المقياس قامت الباحثة بإعداد العبارات المناسبة لكل بعد وقد راعت فيها : -أن تكون العبارات واضحة ومفهومة- الإبتعاد عن الألفاظ الصعبة- الا توحى العبارات بنوع الإستجابة- عدم الإزدواجية للعبارة- أن تقيس العبارات جانب من جوانب البعد الذى تتنمى إلية وقد بلغ عدد العبارات للمقياس في صورته الأولي(آه) عبارة موزعة على (7) أبعاد ملحق (11) والجدول رقم (T I) يوضح أبعاد المقياس وعدد عبارات كل بعد 
جدول (IT)

أبعاد المقياس وعدد عبارات كل بعد

\begin{tabular}{|c|c|c|}
\hline عدد العبارات & الأبعاد & م \\
\hline$\wedge$ & كفايه التخطيط للمحاضره & 1 \\
\hline 1. & كفايه تنفيذ المحاضره & r \\
\hline ir & كفايه اداره المحاضره & r \\
\hline 9 & كفايه استخدام الوسائل التعليميه & $\varepsilon$ \\
\hline 9 & كفايه التقويم & 0 \\
\hline 9 & كفايه الجانب التربوي او الوجداني & 7 \\
\hline 09 & \multicolumn{2}{|c|}{ العدد الإجمالى للعبارات } \\
\hline
\end{tabular}

يوضتح جدول رقم (T/ ) الابعاد وعدد عبارات كل بعد والعدد الكلى للمقياس.

ثم قامت الباحثة بتوزيع المقياس في صورته الأولى على السادة الخبراء للوقوف على مدى انتماء كل عبارة للبعد الذى تتتمى اليه فى المقياس وكذلك إضافة أو حذف أو تعديل صياغة اى عبارات وكذلك لتحديد مدى انتماء هذه العبارات للبعد الخاص بها وتحديد ميزان التقدير الخاص بالمقياس. - المعالجات الإحصائية لاراء الخبراء على العبارات الخاصة بكل بعد :- عن طريق التقدير الكمي والتقدير الكيفي للعبارات ملحق(Y I)، ويوضح جدول (ع I) نتائج تعديل السادة الخبراء على المقياس.

\section{جلول (؛ 1 )}

استطلاع رأي الخبراء في أبعاد وعبارات المقياس

$1 \cdot=\dot{0}$

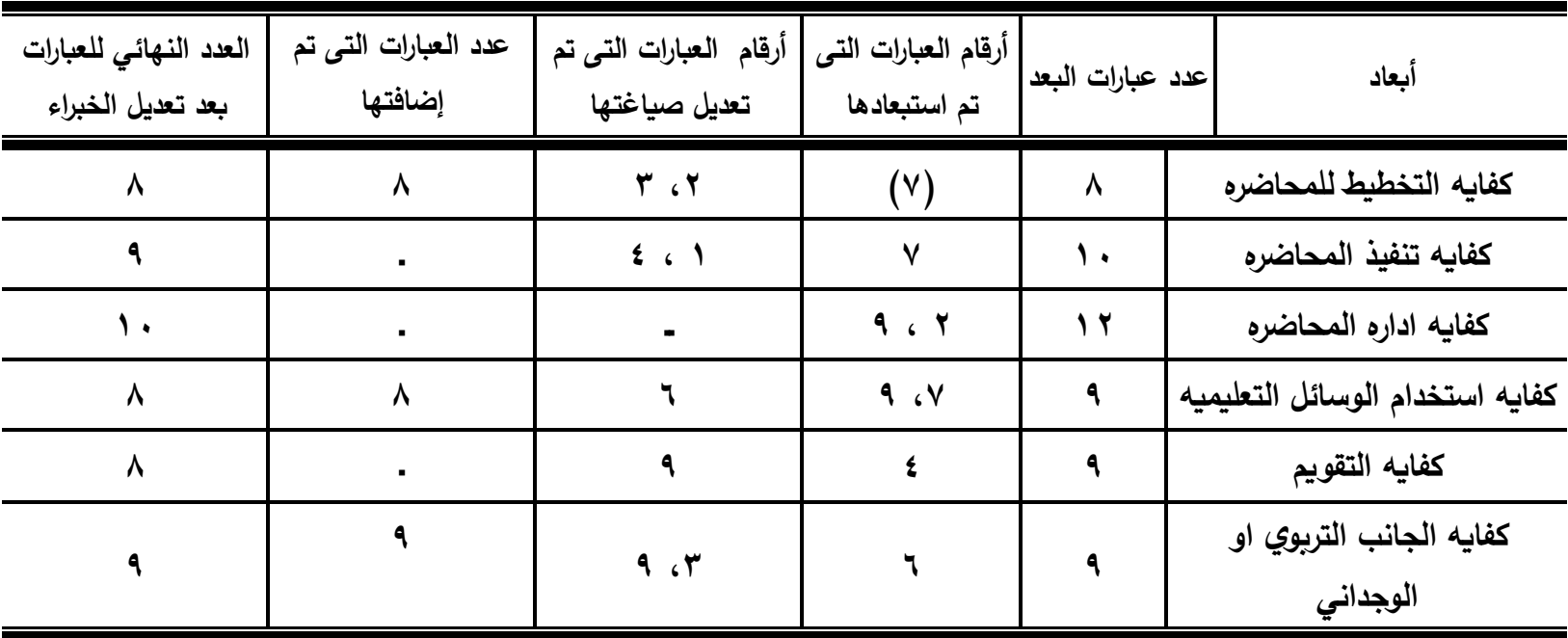




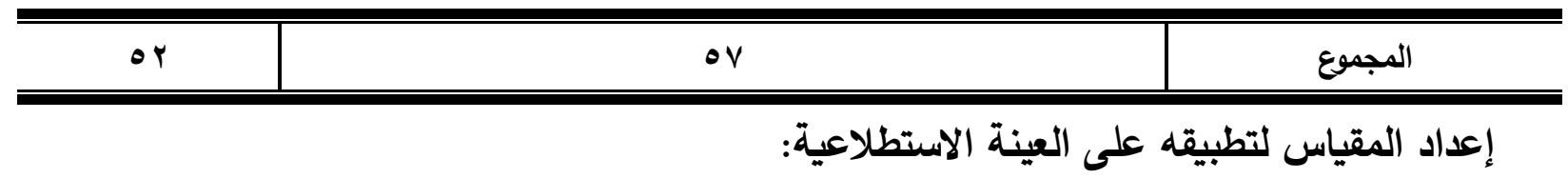

بعد أن تم إعداد المقياس في صورته الثانية وعدد عباراته (YO)عباره موزعة على(T) أبعاد ملحق( I I)، قامت الباحثة بتوزيع عباراته عشوائيا ملحق (ع ا) لكى يتم تطبيقه يوم الثلاثاء

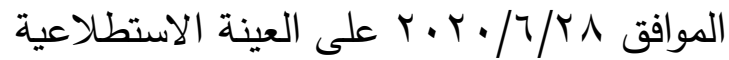

جلول (10)

التوزيع العشوائى لعبارات المقياس للعينة الاستطلاعية

\begin{tabular}{|c|c|c|}
\hline أرقام العبارات موزعة عشوائياً & عدد العبارات & 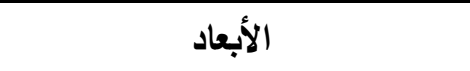 \\
\hline$r r_{6} r V_{6} \varepsilon r 6196 r_{0}, 16 V_{6} 1 T$ & $\wedge$ & كفايه التخطيط للمحاضره \\
\hline 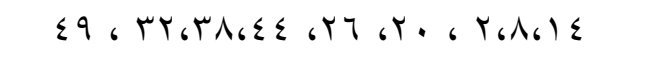 & 9 & كفايه تنفيذ المحاضره \\
\hline 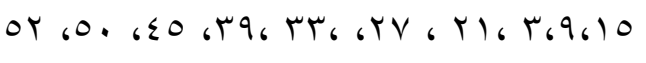 & 1. & كفايه اداره المحاضره \\
\hline 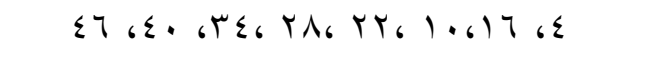 & $\wedge$ & كفايه استخدام الوسائل التعليميه \\
\hline$\sum I_{6} \varepsilon V_{6} r_{0}, r r_{6} r_{9}, 1 V_{6} 0,11$ & $\wedge$ & كفايه التقويم \\
\hline 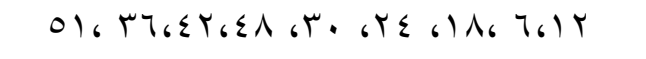 & 9 & كفايه الجانب التربوي او الوجداني \\
\hline
\end{tabular}

حساب المعاملات العلمية لمقياس الكفايات التربويه لاعضاء هيئه التدريس من وجهه نظر

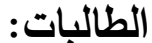

أولاً: حساب صدق المقياس

صدق المحكمين : قامت الباحثة بعرض أبعاد المقياس وعبارات كل بُعد على السادة الخبراء وعددهم( • () خبراء ملحق(1) واعتبرت الباحثة نسبة اتفاق السادة الخبراء على المقياس معياراً لصدقه r- صدق الاتساق الاخلي لعبارات وأبعاد المقياس: قامت الباحثة بحساب الصدق وذلك بحساب قيمة معامل الارتباط بين درجة كل عبارة على حده والدرجة الكلية للبعد الذى تتتمى إليه ودرجة كل بعد والدرجة الكلية للمقياس على عينة الدراسة

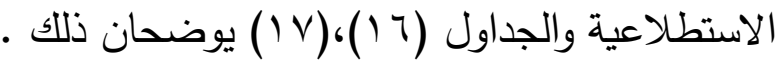




\section{جدول (17)}

معامل الارتباط بين درجة كل عبارة على حدة والدرجة الكلية لكل بعد من أبعاد

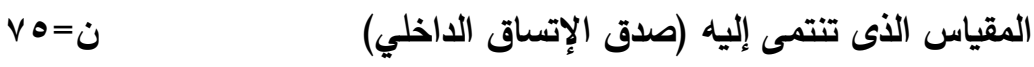

\begin{tabular}{|c|c|c|c|c|c|c|}
\hline كفايه الجانب التربوي & كفايه التقويم & كفايه استخدام الوسائل & كفايه اداره & كفايه تنفيذ & كفايه التخطيط & م \\
\hline$* . .0 \leq 0$ & $*$ * . $\leq \leqslant r$ & * . . Tr & $* . .07 \leq$ & *. . Or & $* .0 \leq 7$ & 1 \\
\hline *. . ror & * . . ๑ & $* \ldots \leqslant \vee V$ & $*$ * . $\{4 \wedge$ & * . . YV0 & $* . .001$ & $r$ \\
\hline *. . 74 & $* . .0 \wedge 1$ & $* .070$ & $* . .0 V Y$ & $*$ *. . $0 \leq$ & *. . rч^. & $r$ \\
\hline$* . .0 \leq r$ & * . .TV & $* \ldots \leqslant 0$ & $* . .7 \leq r$ & $* . . \Delta r V$ & * . . $\leqslant \wedge r$ & $\varepsilon$ \\
\hline$* .7 \leq 0$ & $* . . \Delta \wedge r$ & $* . . \leq \leqslant \mu$ & *.. . & $* . . r . r$ & $* \cdot r \cdot r$ & 。 \\
\hline$* . .011$ & $*$ & $* . . \neg \wedge \Lambda$ & $* .74 \mathrm{~V}$ & $* . .0 \wedge 4$ & *..7V & 7 \\
\hline$* .74$ & $* . . \leqslant 0 r$ & $* .0 Y 4$ & *. . . $10 \leq$ & *..74 & $* . . \leq 9 r$ & V \\
\hline$* * r \leqslant r$ & *.rur & *. . TV0 & *. . orv & $* .0 \wedge 1$ & $* . .0 \leqslant \wedge$ & $\wedge$ \\
\hline \multirow[t]{2}{*}{$*$. . OVo } & & & $* . . \leqslant V r$ & $*$ *.TVr & & 9 \\
\hline & & & $* . .791$ & $* . .711$ & & 1. \\
\hline
\end{tabular}

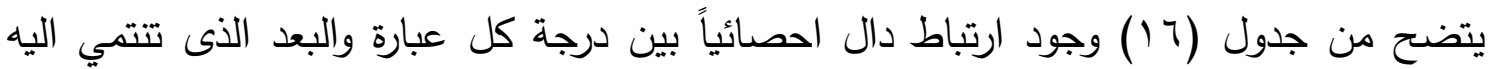
العبارة ، كما يتضح أن جميع معاملات الارتباط دالة عند مستوي الدلالة ه... وهذا يكون مؤشراً لصدق البناء الداخلى لعبارات المقياس المقترح

جدول (iv)

قيم معاملات الارتباط بين درجات كل بعد واللرجة الكلية لمقياس الكفايات التربويه لاعضاء هيئه التدريس من

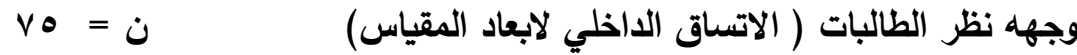

\begin{tabular}{|c|c|c|}
\hline معامل الارتباط & الابعاد الاد & s \\
\hline$* . . T \leqslant \mu$ & كفايه التخطيط للمحاضره & 1 \\
\hline$* .0 \leq 4$ & كفايه تنفيذ المحاضره & r \\
\hline$* . .7 V \leqslant$ & كفايه اداره المحاضره & r \\
\hline$* .07 \varepsilon$ & كفايه استخدام الوسائل التعليميه & $\varepsilon$ \\
\hline$* \cdot . T \leq V$ & كفايه التقويم & $\circ$ \\
\hline *.. & كفايه الجانب التربوي او الوجداني & 1 \\
\hline$* . .704$ & \multicolumn{2}{|c|}{ اللارجة الكلية لمقياس الاتجاهات نحو التعليم الددمج } \\
\hline
\end{tabular}




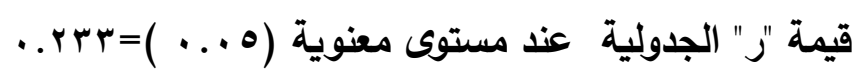

يتضح من جدول (IV) أن قيم معاملات الارتباط بين درجات كل بعد والدرجة الكلية للمقياس

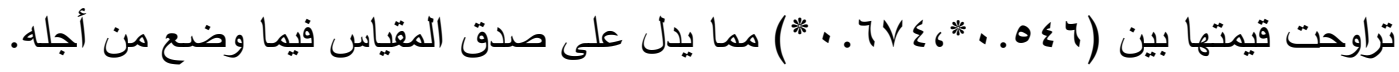
حساب ثبات المقياس: ثانياً:حساب ثبات المقياس: لإيجاد معامل ثبات أبعاد المقياس وعددهم(†)أبعاد بعباراتهم وقامت الباحثة باستخدام:طريقة التجزئة النصفية"سبيرمان وبراون Spearman \& Prown،جتمان "Guttman

جدول (11)

الثبات"بالتجزئة النصفية"و" معامل ألفاكرونباخ "لأبعاد مقياس الكفايات التربويه لاعضاء هيئه التدريس من وجهه نظر الطالبات

\begin{tabular}{|c|c|c|c|c|c|}
\hline \multirow{2}{*}{ كرونباخ ألفا } & \multicolumn{2}{|c|}{ التجزئة النصفية } & \multirow{2}{*}{ العبارات } & \multirow{2}{*}{ 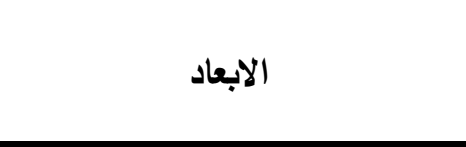 } & \multirow{2}{*}{ s } \\
\hline & 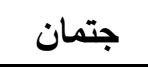 & سيبرمان - براون & & & \\
\hline$* . .7 \leq 0$ & *.. V० & $* . . \vee 0 \leq$ & $\wedge$ & كفايه التخطيط للمحاضره & 1 \\
\hline$* . . v 0 \leq$ & 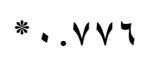 & *..74 & 9 & كفايه تنفيذ المحاضره & r \\
\hline *.. . . & $* .779$ & $*$ *. จ० & 1. & كفايه اداره المحاضره & r \\
\hline$* . \vee v 0$ & $* . \vee \vee 0 \leqslant$ & $* .74 \mathrm{~V}$ & $\wedge$ & كفايه استخدام الوسائل التعليميه & $\varepsilon$ \\
\hline *. . ร & *. . . מ & $* . . \vee r \varepsilon$ & $\wedge$ & كفايه التقويم & 0 \\
\hline$* . . \vee \vee 1$ & $* . \vee \vee 40$ & $* . .70 \leq$ & 9 & كفايه الجانب التربوي او الوجداني & 1 \\
\hline *.. ขฯอ & $* . \vee \vee 9 \wedge$ & $* . . V \leq r$ & or & الارجة الكلية & \\
\hline
\end{tabular}

قيمة "ر" الجدولية عند مستوى 0 . . = بrץ... مستوى الدلالة

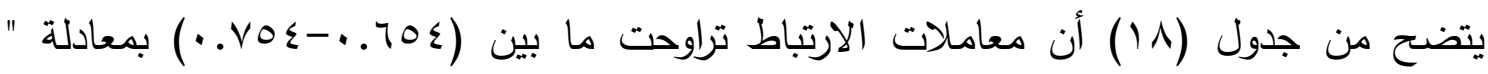
سبيرمان وبراون " وقد تراوحت ما بين (هr . . - . . . . ) بمعادلة " جتمان " وقد تراوحت ما بين

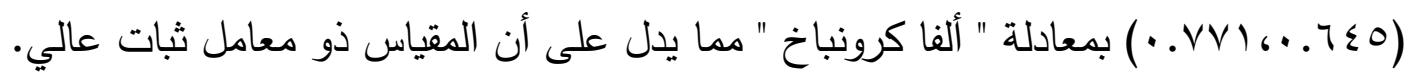
وبعد أن قامت الباحثة بحساب المعاملات العلمية (الصدق - الثبات) للمقياس أصبح فى صورته النهائية جاهز للتطبيق على عينة البحث الأساسية حيث اشتملت عباراته على عدد (Or) عبارة موزعة على ستة أبعاد. (ملحق \& 1 ) طريقة تصحيح مقياس الكفايات التربويه لاعضاء هيئه التدريس من وجهه نظر الطالبات 
تحسب درجات استجابات المقياس على ميزان تقدير ثلاثي (نعم ، أحيانا ، مطلقا) درجاتهم (r r - ( ) على التوالي للعبارات ، وبذلك تكون الدرجة الصغرى للمقياس(ب إه) و الوسطى (ع • () و العظىى (107 ) (107) درجة

\section{الخطوات التنفيذية للبحث :}

قامت الباحثة بتطبيق المقياسين على عينة البحث الأساسية وعددهن( (ro) طالبة في الفترة من

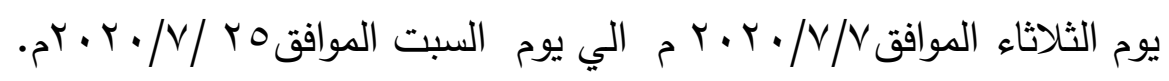

المعالجات الإحصائية: فى ضوء أهداف البحث وفى حدود فروضه تم إجراء المعالجات الاحصائية التالية بإستخدام البرنامج الأحصائى (Spss):

(المتوسط - الوسيط- الانحراف المعياري- الالتواء - معامل الارتباط )

Cرض النتائج ومناقشتها: The Results Offer \& Discussion جلول (19) (19)

معاملات الإرتباط بين أبعاد مقياس الاتجاهات نحو التعليم المدمج وأبعاد مستوي الطموح لاى طالبات الفرقة الرابعه

rฯo $=\dot{0}$

\begin{tabular}{|c|c|c|c|c|c|}
\hline الدرجة الكلية & القدرة على & التفأول & المثابرة & القدرة على الأهدافع & الاتجاهات نحو التعليم المدمكج \\
\hline. .794 & $\cdot . \varepsilon \cdot \varepsilon$ & $.0 \mathrm{Vo}$ & .7 .7 & $\cdot .719$ & البعد المعرفى \\
\hline .79 & $\cdot . \leqslant V$. & $.7 r 0$ & $\cdot .577$ & .01 & البعد التربوي \\
\hline .714 & $-7 \leqslant 1$ & $.0 \cdot r$ & .0 .9 &. .099 & البعد الاجتماعى \\
\hline. $.7 \wedge 1$ &..$\varepsilon I V$ & $\cdot .7 \cdot v$ & $.7 \mathrm{VV}$ & .007 & البعد الانفعالي \\
\hline .079 & $\cdots \varepsilon \wedge q$ & $.71 \varepsilon$ & $.7 v$ & . .Or & البعد السلوكي \\
\hline$\cdot v \cdot 1$ &. .799 & .71. & . . Trr & $.0 r v$ & الارجة الكلية \\
\hline
\end{tabular}

قيمة "ر" الجدولية عند مستوي معنوية (0 . . ) = رسا . .

يتضح من جدول (9 () وجود علاقة إرتباطية دالة احصائياً بين أبعاد الاتجاهات نحو التعليم

المدمج وأبعاد مستوي الطموح لطالبات الفرقه الرابعه. 


\section{جدول (r)}

معاملات الإرتباط بين أبعاد مقياس الاتجاهات نحو التعليم المدمج وأبعاد

مقياس الكفايات التربويه لاعضاء هيئه التريس

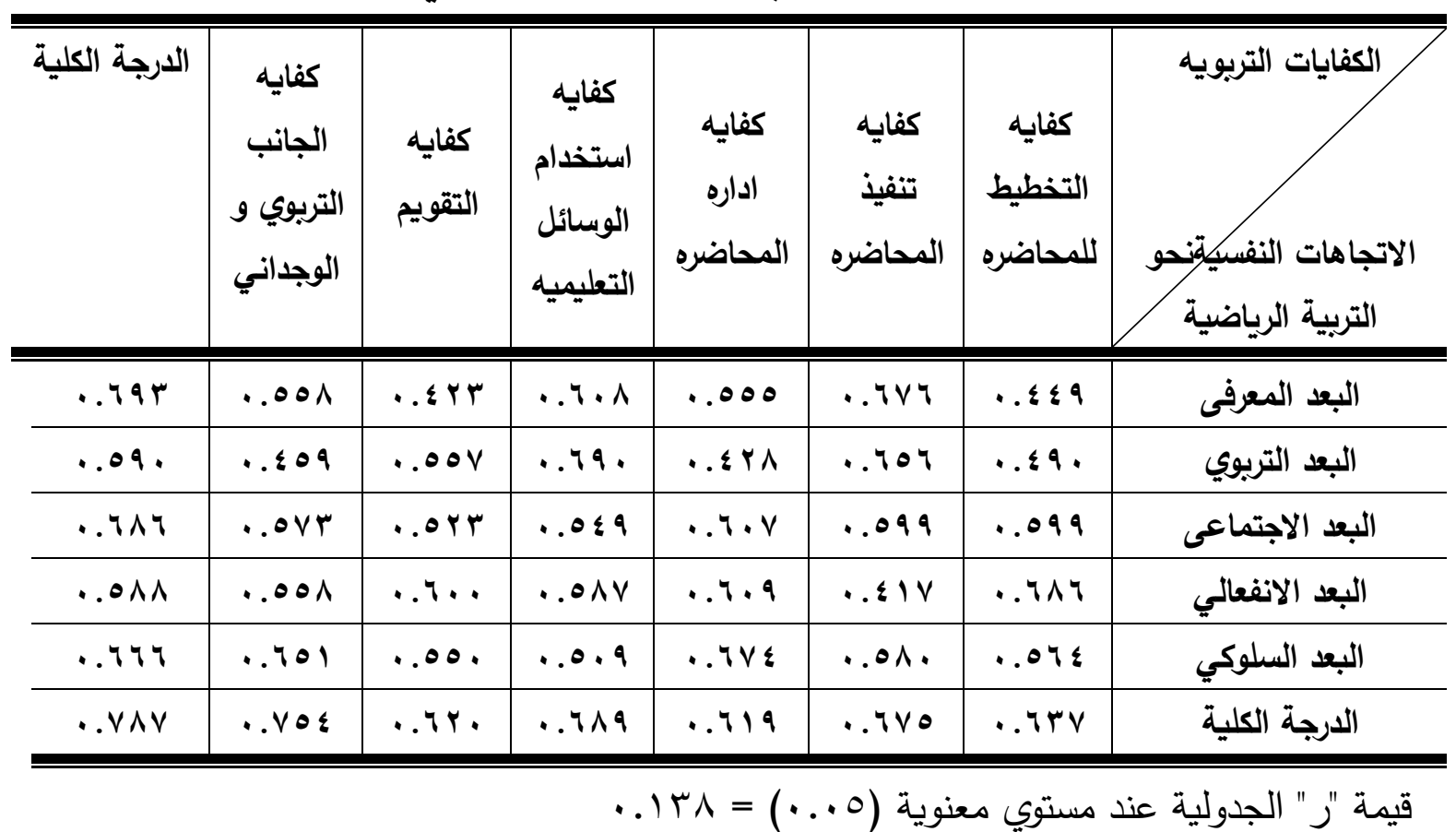

يتضح من جدول (·r) وجود علاقة إرتباطية دالة احصائياً بين ابعاد الاتجاهات نحو

التعليم المدمج وأبعاد الكفايات التربويه لاعضاء هيئه التريس من وجهه نظر طالبات الفرقه الرابعه

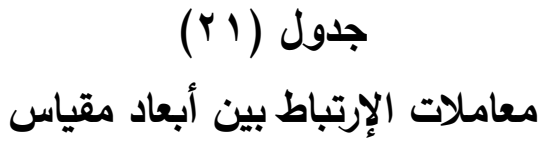

\begin{tabular}{|c|c|c|c|c|c|}
\hline الارجة & القدرة على & 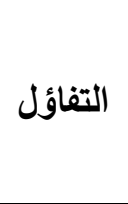 & 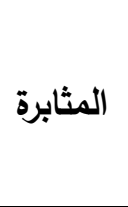 & القدرة على & توى الطموح \\
\hline. $.7 \wedge \wedge$ &. $.00 \mathrm{~V}$ & $.7 \wedge 0$ &. .701 & $.0 \leq$ & كفايه التخطيط للمحاضره \\
\hline. $.7 \vee 0$ &. $.7 \vee 0$ &..$\leqslant 00$ &. $.00 \mathrm{~V}$ &.$\bullet \wedge \bullet$ & كفايه تنفيذ المحاضره \\
\hline$. .7 \leq r$ & $.00 \vee 0$ &. $.7 \cdot 7$ &..$\leqslant \wedge \vee$ & $.70 \leqslant$ & كفايه اداره المحاضره \\
\hline$\ldots \vee \vee 0$ &. $.0 \vee \varepsilon$ &..$\diamond \vee \wedge$ &. $.7 V V$ & $\because \varepsilon 1 \varepsilon$ & كفايه استخدام الوسائل التعليميه \\
\hline. .791 &. $.00 r$ &. $.0 \vee \wedge$ &. $.0 \wedge \mu$ &. $.0 V_{1}$ & كفايه التقويم \\
\hline. $.79 r$ &. .297 & 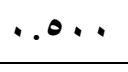 & $\cdot . \varepsilon 9 \mu$ & $.7 \wedge 1$ & كفايه الجانب التربوي و الوجداني \\
\hline . vAr &. $.0 \vee 0$ &. $.71 \%$ & $.7 \vee \wedge$ &. $.79 \wedge$ & الارجة الكلية \\
\hline
\end{tabular}

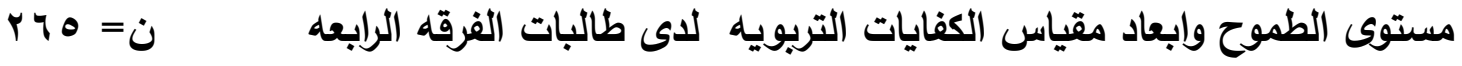




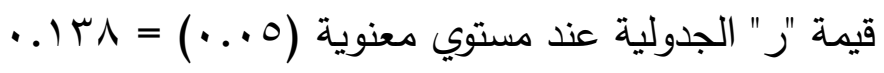

يتضح من جدول (Y) وجود علاقة إرتباطية دالة احصائياً بين ابعاد مقياس مستوي الطموح

$$
\begin{aligned}
& \text { وابعاد الكفايات التربويه لاعضاء هيئه التدريس } \\
& \text { مناقشة الفرض الاول :- }
\end{aligned}
$$

يتضح من جدول (9 (1) وجود علاقة إرتباطية دالة احصائياً بين أبعاد مقياس الاتجاهات نحو التعليم المدمج ومستوي الطموح لدى طالبات الفرقة الرابعه بكلية التربية الرياضية للبنات جامعة الزقازيق. وهذا يدل علي انه كلما ارتفع اتجاهات الطالبات نحو التعليم المدمج كلما ارتفع مستوي الطموح لديهم والعكس صحيح وترجع الباحثه العلاقه بين الاتجاهات نحو التعليم المدمج ومستوي الطموح بانه الطلاب الذين يتسمون بمستوي جيد في الاتجاهات نحو التعليم المدمج يستخدون قدراتهم ومواردهم الذاتيه الشخصيه والبيئيه نحو هذا النوع من التعليم مما يرفع مستوي الطموح لديهم

وكذلك تعزو الباحثه هذه النتيجه الي ان وعي الطالبه بميولها وقدراتها نحو التعليم المدمج ووعيها بمدي اهميته في ظل الظروف الراهنه للمجتمع بشكل عام ولنفسها بشكل خاص يؤثر علي مستوي اتجاهاتها نحو هذا النوع من التعليم مما ينعكس علي مستوي الطموح لديها

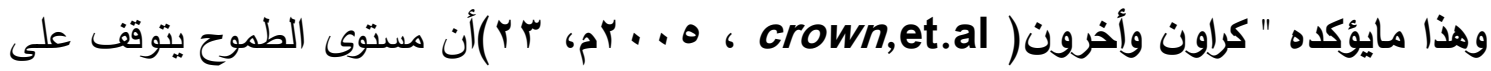
اتجاهات ودوافع الفرد فإن كان لدي الفرد اتجاهات ايجابيه نحو شئ معين فلن يقف فى سبيلة أى عامل أخر فالنجاح كهذف يسعى الفرد لتحقيقة لإشباع حاجة أساسية يصبح الفرد معها أكثر وثوقا فى ذاتة وقدراتة . حيث أنة كلما كان الاتجاه قويا أدى ذلك إلى إحتفاظ الأفراد بمستوى طموح • مرتفع

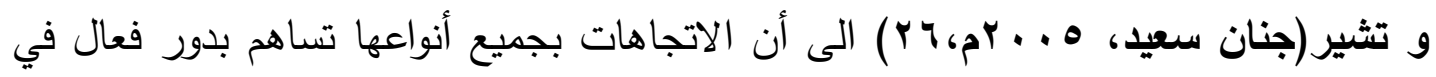
مختلف قطاعات المجتمع إذا ما عُززت بشكل ايجابي عن طريق معالجة الاتجاهات السلبية لدى المجتمع وخاصة لدى الطالبات عن طريق معرفه أهمية التعليم المدمج في المجتمع وتوجيه الأنظار إلى مدي اهميته وخاصه في ظل مستحدثات كورونا 


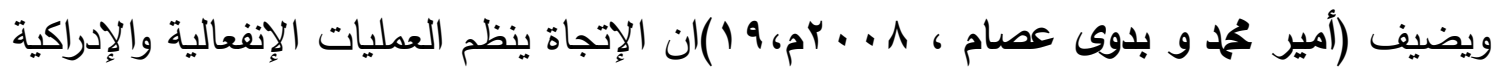
والمعرفية ويحدد إستجابات أو سلوك الأفراد نحو الموضوعات والأنشطة المختلفة . وعلى هذا الأساس فإن إتجاهات الطلاب نحو التعليم المدمج ستؤثر بالتأكيد فى مستوي الطموح لديهم

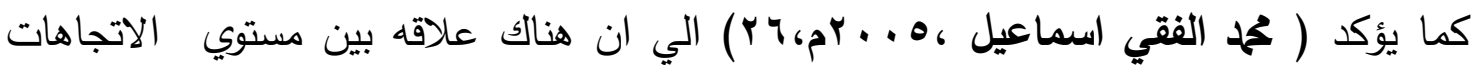
الايجابيه ومستوي الطموح حيث ان الطلاب ذوي الاتجاهات الايجابيه المرتفعه يتمتعون بمستوي عال من من الطموح بعكس ذوي الاتجاهات السلبيه .

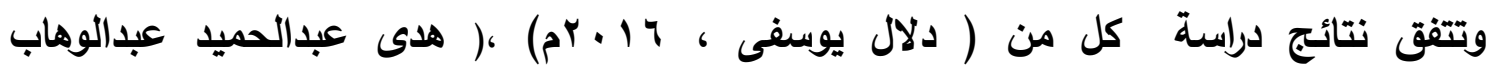

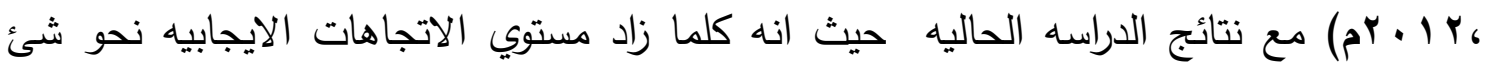
معين كلما زاد معه مستوي الطموح لديه اي ان هنالك علاقه طرديه بينهما .

وبذلك تحقق الفرض الاول الذي ينص علي توجد علاقة بين الاتجاهات نحو التعليم المدمج ومستوي الطموح لدى طالبات كليه التربيه الرياضيه بنات جامعه الزقازيق. مناقشة الفرض الثاني :- من يتضح من جدول (·r) وجود علاقة إرتباطية دالة احصائياً بين أبعاد مقياس الاتجاهات نحو التعليم المدمج وابعاد مقياس الكفايات التربويه لاعضاء هيئه التدريس من وجهه نظر طالبات الفرقة الرابعه بكلية التربية الرياضية للبنات جامعة الزقازيق. وترجع الباحثه هذه العلاقه الطرديه بين ابعاد مقياس الاتجاهات نحو التعليم المدمج وابعاد مقياس الكفايات التربويه لاعضاء هيئه التدريس من وجهه نظر الطالبات الي مدي وعي الطالبات بمدي اهميه التدريس الجيد والفعال وخاصه في ظل ظروف مستحدثات كورونا التي اجبرت العالم اجمع علي التعامل عن بعد وكانت العمليه التعليميه هي الجزه الاهم في هذه الظروف حيث ان التعليم الجامعي اعتمد في ذلك المنظومه علي الاستاذ الجامعي الذي يعد احد اهم مقومات العمليه التعليميه والتربويه وما يملكه من الكفايات التربويه والتدريسيه التي تؤهله الي تزويد الطالبات بالمعلومات والمعارف والخبرات والاتجاهات والمهارات التي تساعد في اعدادهم اعدادا علميا وفكريا واخلاقيا ومهنيا لمواكبه احتياجات سوق العمل بدون المساس بالعمليه التعليميه في ظل تلك الظروف ولذلك كان هناك علاقه طريه بين اتجاهات الطالبات نحو التعليم المدمج والكفايات التربويه لاعضاء هيئه التدريس • 


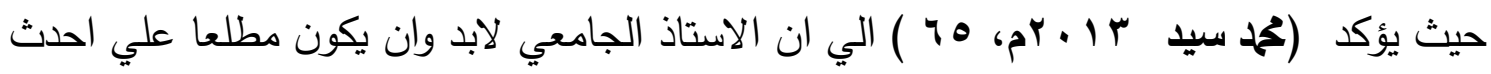
التطبيقات التربويه وممارستها لان من مظاهر التدريس الفعال هو مواكبه العصر واستخدام احدث التقنيات الحديثه وتوظيفها في مجال التدريس •

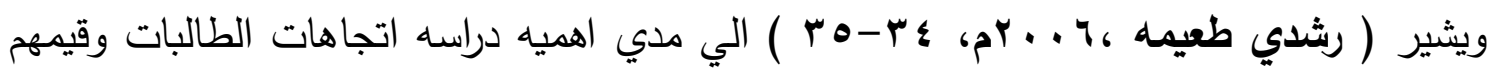
وطموحاتهم وترجمه هذا كله الي كفايات تربويه يجب ان تتوافر في عضو هيئه التدربيس الذي هي - ميتصل بهم

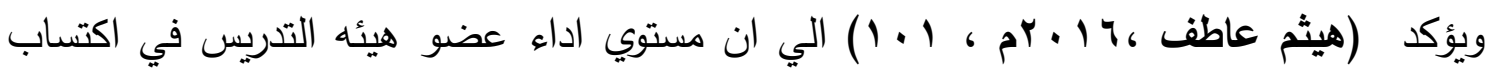
الكفايات وتوظيفها واستخدامها يلعب دورا رئيسيا في رفع مستوي فاعليه التعليم والتعلم ولها تاثير ايجابي علي الاداء التربوي والمهني لعضو هيئه التدريس وبالتالي يسهم في تحسين العمليه التعليميه مما يؤدي بدوره الي ايجابيه اتجاهات الطالبات نحو التعليم المدمج في ضوء مايتوافر لعضو هيئه التدريس من كفايات تربويه .

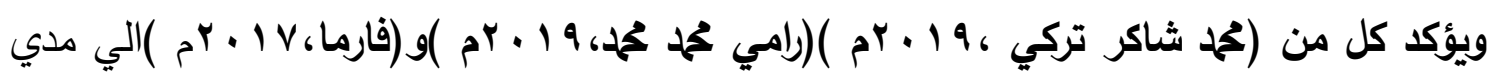
اهميه تحديد الاهداف التي يعمل من اجلها عضو هيئه التدريس والاستفاده من تكنولوجيا التعليم لتحقيق فاعليه تلك الاهداف والاستراتيجيات من خلال استخدام القواعد العلميه في التخطيط والمنهج العلمي للعمل فضلا عن استخدام الكفايات التربويه والموارد والاجهزه والادوات التعليميه المختلفه مما يؤدي الي ايجابيه الاتجاهات نحو التعليم المدمج • ذائمات

Carlson ويتفق ذلك مع نتائج دراسة(هبة الله علي رشوان، 1 • ب م)ودراسة) كارلسون

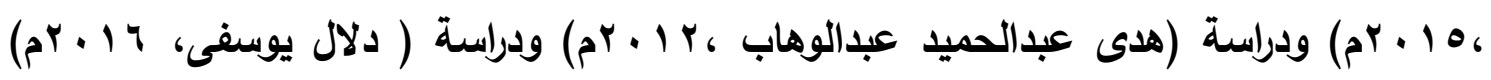
وكانت أهم النتائج أن إستخدام اساليب التدريس المختلفة ومنها التعليم المدمج أدى إلى تحسين السلوك الإيجابى لعضو هيئه التدريس وتحسين قدرتة على وجود المناخ التحفيزى مما ادى إلى إلى ايجابيه اتجاهات الطالبات نحو التعليم المدمج • وبذلك تحقق الفرض الثاني الذي ينص علي توجد علاقة بين الاتجاهات نحو التعليم المدمج والكفايات التربويه لاعضاء هيئه التدريس لدى طالبات كليه التربيه الرياضيه بنات جامعه الزقازيق.

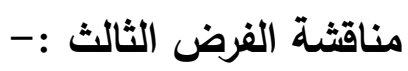
يتضح من جدول (Y) وجود علاقة إرتباطية دالة احصائياً بين أبعاد مقياس مستوى الطموح والكفايات التربويه لاعضاء هيئه التدريس لدى طالبات كليه التربيه الرياضيه بنات جامعه الزقازيق. 
وترجع الباحثه وجود تلك العلاقه الي انه كلما امتلك عضو هيئه التدريس الكفايات التربويه والتدريسيه اللازمه كلما كان ملما بالمعارف والمعلومات التي تجعله يستطيع مواكبه المستجدات والتطورات ليكون قادرا علي اداء المهام الموكله اليه علي اكمل وجهه وبالتالي ينعكس ذلك علي مستوي دافعيه وطموح الطالبات نتيجه امتلاك عضو هيئه التدريس لتلك الكفايات

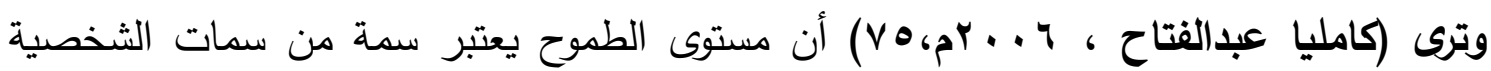
الإنسانية أى أنها صفة موجودة لدى كل أفراد المجتمع , ولكن بدرجات متفاوتة فى الثدة والنوع وهى تعبر عن التطلع لتحقيق أهداف مستقبلية قريبة أو بعيدة ـ وإن شعور الإنسان بالكفاءة الذاتيه او الكفاءه من المحيط الخارجي به يرفع مستوى الطموح لدية , فى المقابل فإن شعورة بعدم الكفاءة يعمل على خفض مستوى الطموح لدية.

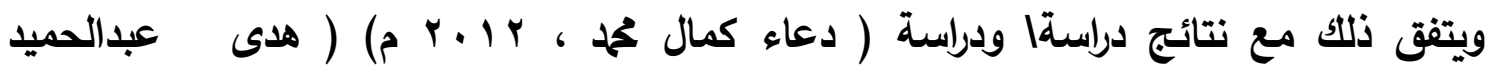

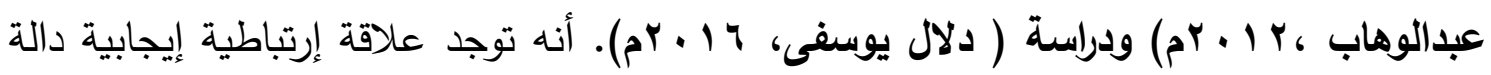

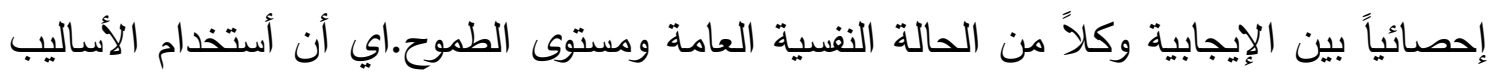
الحديثة فى التدريس وامتلاك عضو هيئه التدريس للكفايات التربويه اللازمه أدت إلى زيادة الدافعية نحو التعلم , وأن زيادة الدافعية أدى إلى تحسين مستوى الطموح لديهم. ويؤكد ( احمد حسن ،ه . . بم، 00) ان من اهم مسئوليات عضو هيئه التدري في القرن الحادي والعشرين هو تكوين واعداد مخرج تربوي قادر علي المواجهه والتكيف مع مختلف التحديات المعاصره ولن ياتي ذلك الا اذا كان عضو هيئه التدريس يتمتع بالكفايات التربويه اللازمه للتدريس وللعمليه التعليميه ككل وبالتالي يكون قادرا علي ضمان تعليم مناسب ورفع مستوي طموحات الطالبات المات

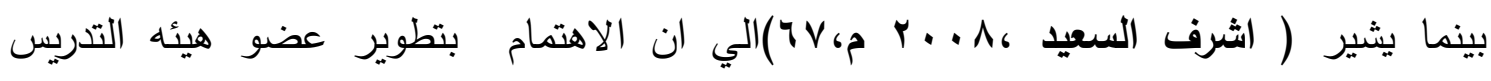
وضمان الجوده في ادائه والارتقاء بمستوي ممارسته جاء كاستجابه حتميه لمنطق العصر ومواجهه التحديات التربويه والتعليميه الححيثه والتي بدورها تؤدي الي رفع مستوي الطموح والدافعيه لدي

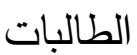

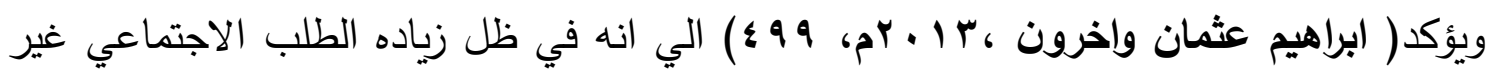
المسبوق علي التعليم كنتيجه طبيعيه لزياده وعي الافراد والمجتمعات بتتميه التعليم فقد بات من من المؤكد ان اهم معايير الحكم علي مدي فاعليه الجامعات اليوم تتمثل في مدي نجاحها في تلبيه الطموح التعليمي المتفجر للي الطلاب ذوي الخلفيات الاجتماعيه والثقافيه والاقتصاديه المتباينه 
بينما يضيف (عحم شاكر ، 19 • Y ، ؛ \& ) ان نجاح عضو هيئه التدري في القيام بادواره الجديده المتوقعه يستلزم امتلاكه لبعض من الكفايات التربويه والقدرات التي يختلف بدورها عن تلك التي يمتلكها عضو هيئه التربس اليوم مما يعني ضروره تحديث وتطوير برامج اعداد عضو هيئه التدريس قبل العمل كذللك البرامج الموجهه للتميه المهنيه المستمره اثناء الخدمه وذلك ضمانا لرفع وتتميه قدراته ومهاراته مما يعمل علي رفع مستوي الطموح لدي الطالبات . ويشير ( ميديلي، Y I · r م) الي ان عضو هيئه التدري المعاصر الفعال صاحب المعرفه العميق هو وحده القادر علي توفير هذه النوعيه من التعليم والاستجابه لحاجات طلابه وطموحاتهم وملائمه الفروق الفرديه بينهم واختلافهم لما يضمن لهم جميعا النجاح بل التفوق في تحقيق الاهداف التعليميه والتربويه وبذلك تحقق الفرض الثالث الذي ينص علي" توجد علاقة بين مستوى الطموح والكفايات التربويه لاعضاء هيئه التدريس لدى طالبات كليه التربيه الرياضيه بنات جامعه الزقازيق". الاستخلاصات والتوصيات :

الاستخلاصات :-

ا - توجد علاقة بين الاتجاهات نحو التعليم المدمج ومستوي الطموح لاى طالبات كليه التربيه

الرياضياه بنات جامعه الزقازيق. ץ- توجد علاقة بين الاتجاهات نحو التعليم المدمج والكفايات التربويه لاعضاء هيئه التدريس لدى طالبات كليه التربيه الرياضيه بنات جامعه الزقازيق. ז- توجد علاقة بين مستوى الطموح والكفايات التربويه لاعضاء هيئه التدريس لدى طالبات كليه التربيه الرياضيه بنات جامعه الزقازيق.

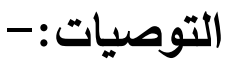

انطلاقا من أهداف البحث ، وما تم التوصل إليه من نتائج ومقارنتها بنتائج الدراسات السابقة فان الباحثه توصي بما يلي:• حث الأساتذة للطالبات وتوعيتهم بأهمية التعليم المدمج وخاصه في ظل ظروف جائحه كورونا وذللك لتنمية الإتجاة الإيجابى لديهن بأهمية التعليم المدمج في العمليه التعليميه. * حث الأساتذة على البحث في تطوير أساليب وطرق تدريس الحديثه وذلك لتتمية الإتجاة الإيجابى وزيادة الطموح والدافعيه نحو التعلم. 
* توصي الباحثه بضروه توافر الامكانات الماديه والبشربيه لتذليل اي صعوبات تواجه هذا النوع من التعليم

• توصي الباحثه بضروره تنميه قدرات وكفايات اعضاء هيئه التدريس بما يتلائم مع تغييرات العصر بصفه دوريها ـان. * توصي الباحثه بضرورة تهيئة المناخ الدراسى والتحفيزي للطالبات لزياده اتجاهاتهم الايجابيه نحو التعليم المدمج وزياده مستوي طموحاتهم • توصي الباحثه بتحويل موقف عضو هيئه التدريس الجامعي من ناقل للمعرفه او المعلومه الي موجهه ومشرف وشريك في المواقف التدريسيه والتربويه

\section{المراجع}

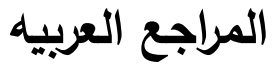

ا. ابراهيم عثمان واخرون( r • rr) : علم الاجتماع التربوي ، الشركه العربيه المتحده للتسويق والتوريدات ، القاهره ،طا

ץ. احمد حسين الصغير ( ه. . rم ): التعليم الجامعي في الوطن العربي تحديات الواقع ورؤي المستقبل ، عالم الكتب ، القاهره ، طا

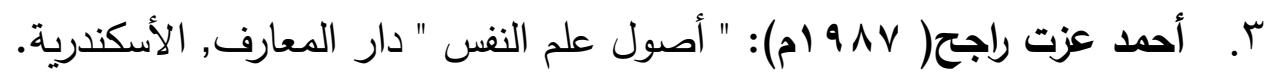
ع. اشرف السعيد احمد (^ . . r م): الجوده الشامله في المؤسسات التعلييمه بين رؤيه مابعد الحداثه والروايه الاسلاميه ، دار الجامعه الجديده ، الاسكندريه

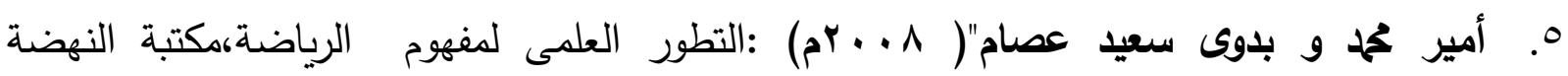
المصرية ، بمدية

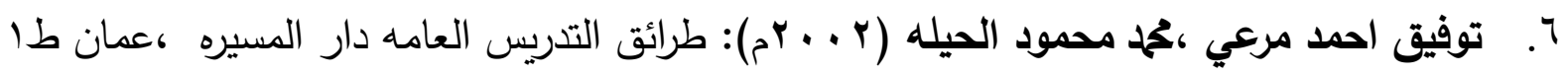

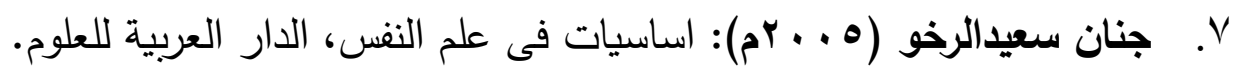

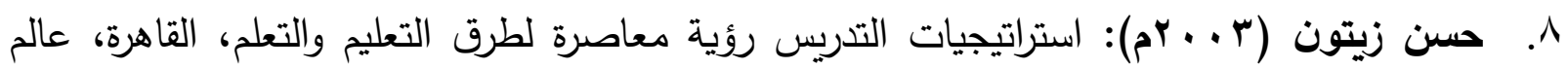
الكتب

9. حسن شحاتة، زينب النجار (r . . rم): "معجم المصطات التربوية والنفسية"، القاهرة، الدار المصرية اللبنانية. • ا. حسن علي سلامه (ه . . بم): التعليم الخليط / التطور الطبيعي للتعلم الالكتروني ، المجله 


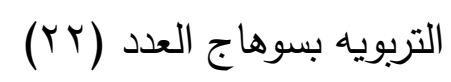

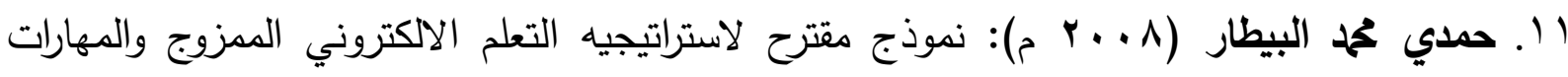

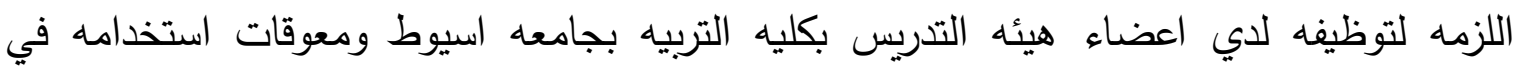

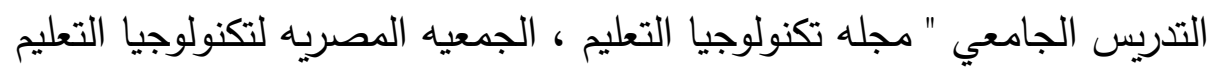

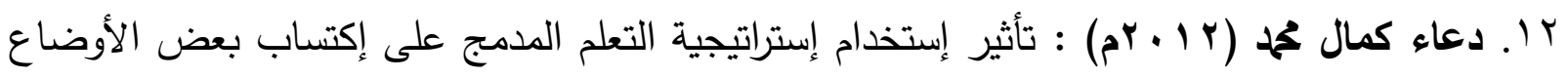

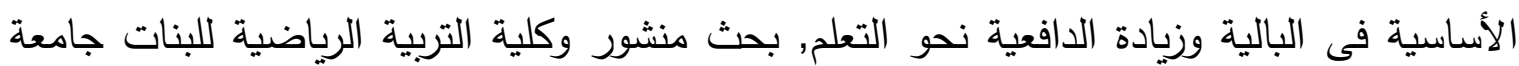
الزقازيق

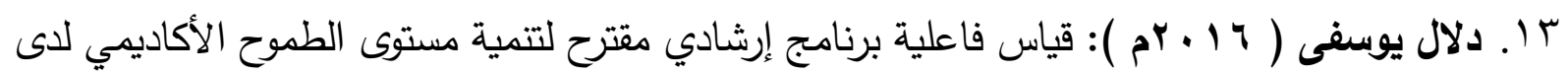

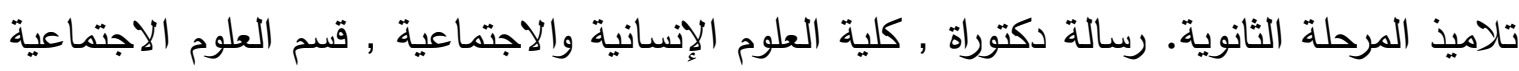
- الجزائر,

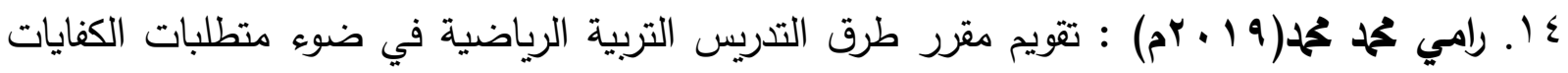

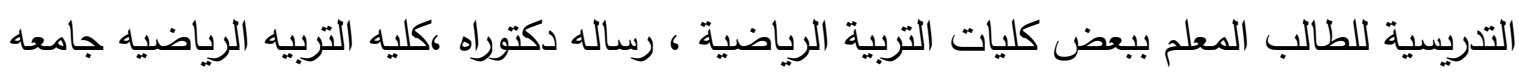
المنصوره

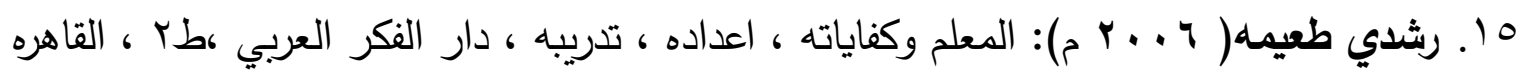

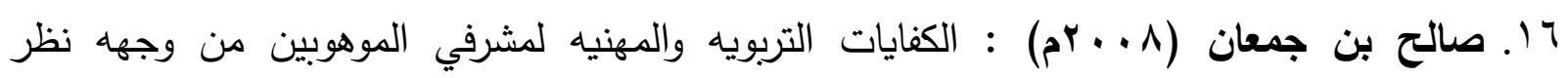
المشرفين المتخصصين والمعلمين المتعاونين ، مذكره لنيل درجه الماجستير ، كليه التربيه جامعها ونه وهيه القري ، المملكه العربيه السعوديه

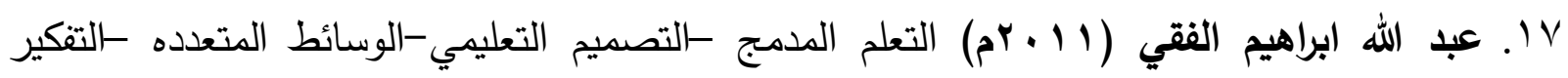

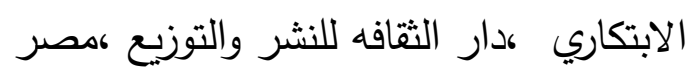

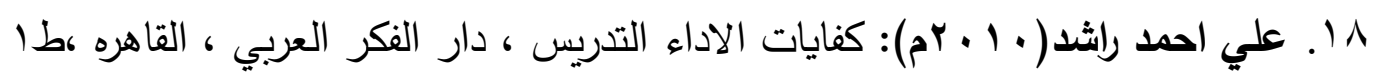

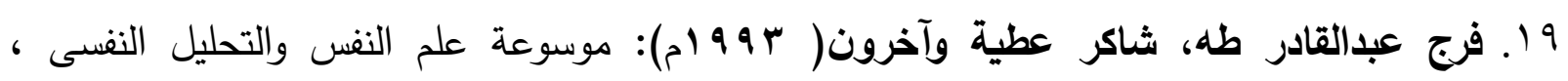
بالقاهرة، دار سعاد الصباح.

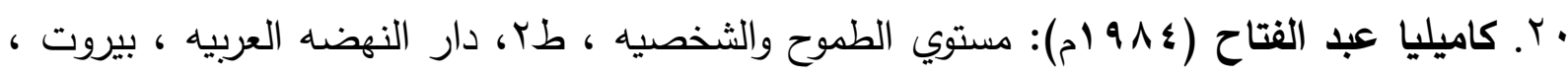
لبنان

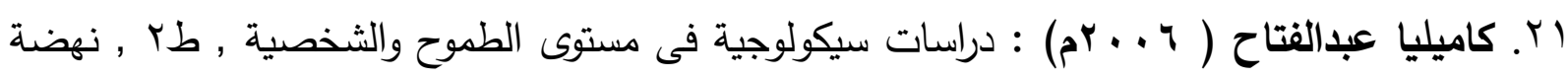
مصر , القاهرة. r r. ماجد عاطف إبراهيم الإسي (9 (1 +rم): فاعلية برنامج تدريبي في تتمية كفايات تدريس اللغة العربية

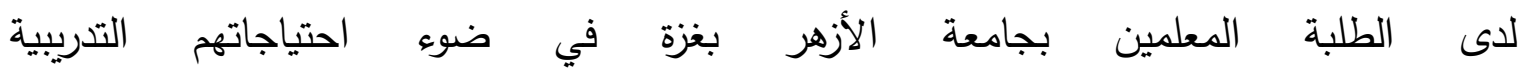


رسالله دكتوراه ،كلية البنات للآداب والعلوم والتربية جامعة عين شمس

بr. مجدي محمود فهيم تحمد( 9 + . rم): الاسس العلميه والعمليه لطرق التدري ، دار الوفاء لدني الطباعه والنشر ، الاسكندريه

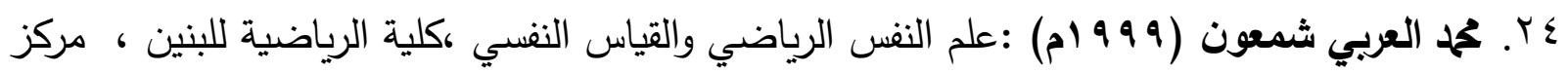

الكتاب للنشر ، جامعة حلوان.

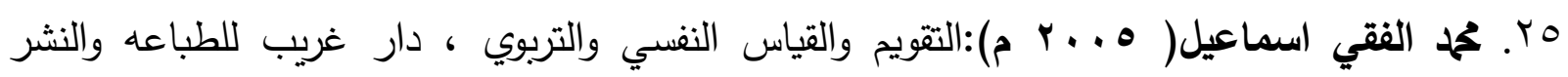
والتوزيع ، القاهره

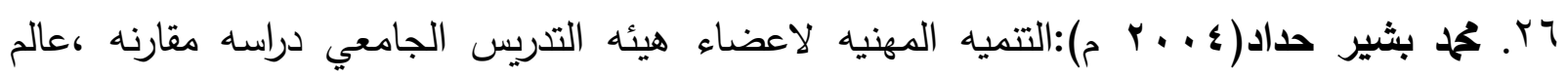

الكتب ، القاهره طـا

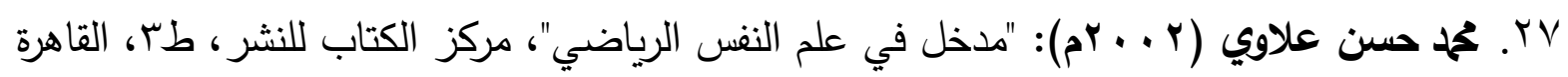

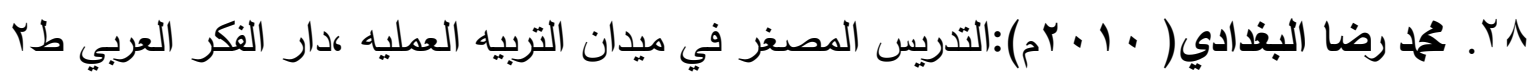

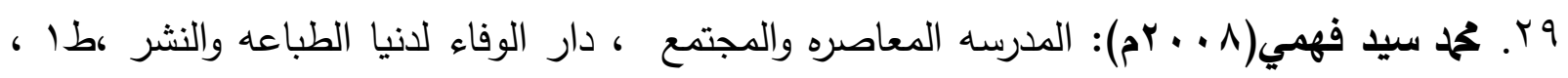

الاسكندريه

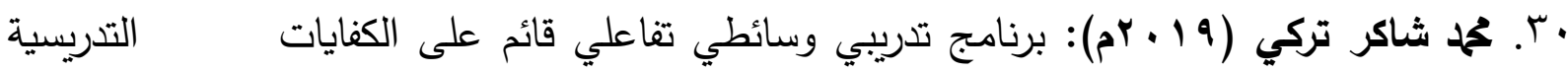
مدعوما بالوسائط التفاعليه واثره في تتميه الاداء التدريسي لدي معلمي الدراسات الاجتماعيه في المرحله الاساسيه بالادردن واتجاههم نحوه ، رساله دكتوراه ،كليه التربيه ،جامعه المنصوره ابr. محمد كامل الناقه(9AV ام) : البرنامج التعليمي القائم علي الكفايات ، اسسه واجراءاته ، شركه مطابع الطوبجي، القاهره rrr. عحمد محمد عبدالله الحماحمي (10 • 10م): "بناء مقياس للإتجاهات نحو الرياضة للجميع"، المجلة

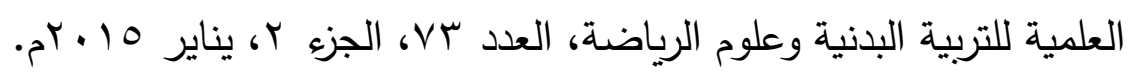
سب. مني عبد الحليم (q . . rم) :الاتجاهات البحثية المعاصرة في علم النفس الرياضي، دار الوفاء لدنيا الطباعة والنشر ، جامعة الاسكندرية

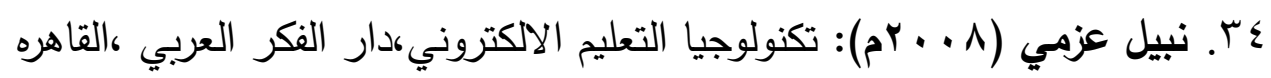
هب. نهله سيد أحمد (•r • r م):تاثير استخدام التعليم المدمج (الموقع الالكتروني -التعلم التعاوني ) علي مستوي الاداء المهاري لسباحه الزحف علي البطن ،رساله ماجستير ، كليه التربيه الرياضيه بنين وبنات جامعه بورسعيد جب. هبة الله علي رشوان (0 إم): تأثثر دراسة مقرر تاريخ وفلسفة التربية الرياضية على الإتجاهات 
الفلسفية الإيجابية نحو ممارسة النشاط البدني لطالبات كلية التربية الرياضية بنات جامعة الزقازيق.

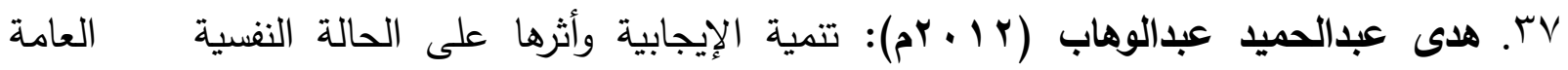

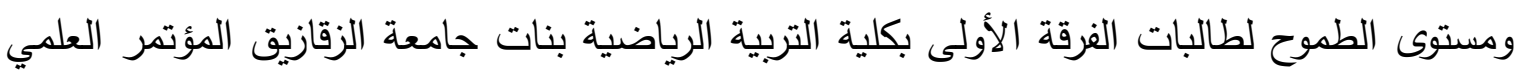

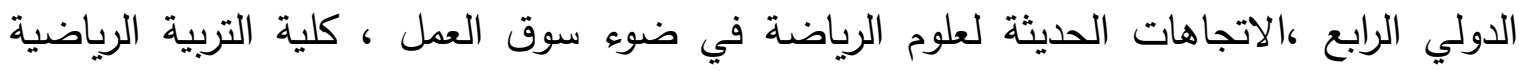

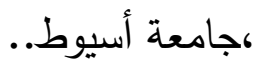

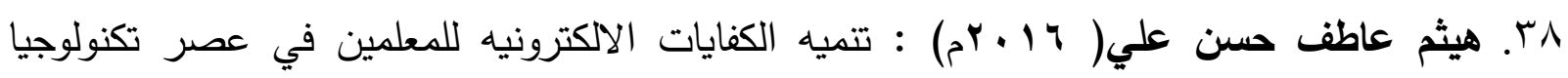

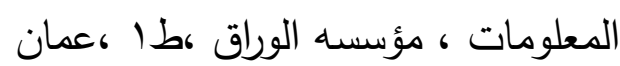

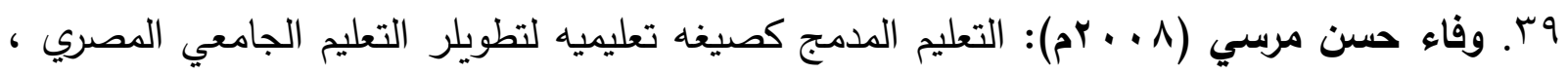
فلسفته ومتطلبات تطبيقه في ضوء خبرات بعض الدول / مجله رابطه التربيه الحديثه . . المراجع الاجنبيه

40- Akkoyunlu, b\&Soylu, M.(2016). A Study on students' Views About Blended Learning Environment. Journal of Distance Education, 7 (3), 43-56. Attitude Formation And Associated Behavior In Physical Educator.

41- Bohner \& Wanke,( 2002): "Attitudes and Attitudes change", Hove UI Psychology Press.

42- Carlson T.B. (2001): Why Students Halt Or Love QYM: Astute or

43- Crown, DougLas P.. Conn Lane K. MarLowe, David ; EdwardS, CarL N. ( 2005 ). Some deveLOpmentaL antecedents of LeveL of aspiration. JournaL of personality. VoL. 37(1),march, p.p 73-92

44- -Ding ,Y. \& Hao F. (2009). "Using a simulation laboratory to improve physics learning: A case exploratory learning of diffraction .Free Press, New York, NY, 1982 grating." Etcs, vol. 3, First International Workshop on Education 
Magazine, pp1-6, Retrieved. 4/11/2014 from

45- -Medley, D.M. (2012). Teacher effectiveness, Encyclopedia of Educational Research. 5th ed., The

46- -Reason, CK\&Stavkin, M.(2005). Questioning the Hybrid Model:

student outcomes in different courses formats. JALN, 9(1), 83-94.

Retrieved. 3/4/2014

Retrieved. 3/4/2014 from

47- Ginnis, M.(2005). Building a successful blended - strategy.ITI

Learning

.Technology and Computer Science

48- Varma ,Charu .(2017).Impr oving Qualit y of Element ar y Educat ion By Monit or ing Pr ofessional Compet encies of Teacher $s$ for Inclusive Educat ion, ERIC-Education Resources Information Center (ED494892

مواقع شبكه المعلومات الدوليه

49-http://tojde.anadolu.edu.tr/tojde3/articles/article.htm

50-http://www.itmapgazine.com/Ttimagazine/article/detail.Jsp?ld 167425 